\title{
Article
}

\section{Interactive effects of composted green waste and earthworm activity on tree growth and reclaimed soil quality: a mesocosm experiment}

Ashwood, Frank, Butt, Kevin Richard, Doick, Kieron J. and Vanguelova, Elena I.

Available at http://clok.uclan.ac.uk/18818/

Ashwood, Frank, Butt, Kevin Richard ORCID: 0000-0003-0886-7795, Doick, Kieron J. and Vanguelova, Elena I. (2017) Interactive effects of composted green waste and earthworm activity on tree growth and reclaimed soil quality: a mesocosm experiment. Applied Soil Ecology, 119 . pp. 226-233. ISSN 0929-1393

It is advisable to refer to the publisher's version if you intend to cite from the work. http://dx.doi.org/10.1016/j.apsoil.2017.05.018

For more information about UCLan's research in this area go to http://www.uclan.ac.uk/researchgroups/ and search for < name of research Group>.

For information about Research generally at UCLan please go to http://www.uclan.ac.uk/research/

All outputs in CLoK are protected by Intellectual Property Rights law, including Copyright law. Copyright, IPR and Moral Rights for the works on this site are retained by the individual authors and/or other copyright owners. Terms and conditions for use of this material are defined in the policies page. 
Interactive effects of composted green waste and earthworm activity on tree growth and reclaimed soil quality: a mesocosm experiment.

Frank Ashwood ${ }^{a *}$, Kevin R. Butt ${ }^{b}$, Kieron J. Doick ${ }^{a}$ and Elena I. Vanguelova ${ }^{a}$

a Forest Research, Alice Holt Lodge, Farnham, Surrey, GU10 4LH

${ }^{b}$ University of Central Lancashire, Preston, Lancashire, PR1 2HE

*Correspondence:

Frank Ashwood

Soil Sustainability Research Group

Forest Research

Alice Holt Lodge

Farnham, Surrey, United Kingdom

francis.ashwood@forestry.gsi.gov.uk 


\begin{abstract}
On reclaimed landfill sites, the addition of organic matter such as composted green waste (CGW) to soil-forming materials can support tree survival and growth. CGW addition may also assist the establishment of sustainable earthworm populations, and in turn these organisms can promote further soil development through their burrowing and feeding activity. Despite such potentially mutual benefits, little research has been carried out into CGW and earthworm interactions with trees on reclaimed land. A twelve month, open field nursery experiment revealed the responses of the interactions between two tree species; Alnus cordata (Betulaceae) and Acer platanoides (Sapindaceae), CGW and the earthworms Aporrectodea longa (Lumbricidae) and Allolobophora chlorotica (Lumbricidae) in reclaimed soil. Controlled mesocosm conditions permitted a detailed investigation into the factors affecting tree growth and nutrient uptake, soil nutrient cycling and earthworm population dynamics. Results revealed that $A$. cordata growth was unaffected by CGW or earthworm addition. There was, however, a significant positive synergistic effect of earthworm activity and CGW addition on $A$. platanoides growth. CGW addition significantly increased levels of organic carbon and essential plant macro-nutrients in reclaimed soil while earthworm activity assisted decomposition of both leaf litter and CGW. Findings showed that CGW may serve as a suitable early source of organic matter to support earthworm population establishment on reclaimed sites. This experiment demonstrates that CGW improves reclaimed soil quality, thereafter supporting tree establishment and growth on reclaimed landfill.
\end{abstract}

Keywords: Landfill restoration; tree species; organic waste; soil quality; synergistic effect 


\section{Introduction}

Creation of a suitable soil resource is essential for sustainable greenspace establishment, to provide necessary soil chemical and physical conditions and restore normal soil biological functions (Scullion, 1992). There is increasing industrial and scientific interest in improving the soil materials used in reclamation projects, particularly through the addition of organic matter from waste streams, such as Composted Green Waste (CGW) (Foot et al., 2003; Moffat, 2006; Nason et al., 2007; Forest Research, 2015). However, at present there is limited research into the effect of CGW on tree growth and soil quality on reclaimed land (Ashwood et al., 2014). The few available field experiments have demonstrated some benefits of CGW on tree establishment, and this appears to be dependent on the rate and depth of incorporation (Foot et al., 2003; Moffat et al., 2008).

The addition of organic waste materials to reclaimed soil may also enable the establishment of sustainable earthworm populations, which can in-turn support tree growth and the delivery of ecosystem services (Lowe and Butt, 2002, 2004; Blouin et al., 2013). Certain earthworm species (e.g. anecic, deep-burrowing) actively incorporate and mix organic waste materials into soils, enhancing mineralisation and benefiting soil fertility (Piearce and Boone, 1998; Lowe and Butt, 2002). The addition of earthworms may therefore be an effective way to enhance the benefits of organic wastes such as CGW during land reclamation. However, studies into the utilisation of earthworms during the restoration of brownfield sites to woodland are few in number, and have experienced limited success, particularly due to inappropriate earthworm species selection and the use of excessively hostile substrates without sufficient amendment (see the reviews of Butt, 1999, 2008). Those studies which have investigated the influence of earthworms on forest tree species in natural soils have mostly observed a positive influence of earthworms on tree growth (e.g. Marshall, 1971; Haimi et al., 1992; Muys et al., 2003; Welke and Parkinson, 2003; Larson et al., 2010). However, such results are unlikely to be directly comparable to the specific conditions presented by reclaimed land.

There is overwhelming agreement that tree species differently influence soil quality and soil faunal population development through the quality and quantity of their leaf and root litter (Swift et al., 1979; Pigott, 1989; Muys et al., 1992; Reich et al., 2005; Rajapaksha et al., 2013). It is therefore of value, when planning land reclamation to a woodland end-use, to understand whether the tree species planted are likely to provide litter which enables native soil faunal communities to establish, thus supporting soil development and local ecosystem service provision (Kibblewhite et al., 2008; Rajapaksha et al., 2013). Certain tree species, such as Alnus cordata and Acer platanoides are recommended for planting on reclaimed or ex-industrial land, based on their tolerance to high soil $\mathrm{pH}$ and dry soil conditions, and potential for SRF based on fast growth rates (Hibberd, 1986; Forest Research, 2011). Currently however, there is a paucity of knowledge regarding the interaction between these two non-native tree species and native UK soil biota, making these pertinent tree species to investigate further and compare to previous research with similar native species (Rajapaksha et al., 2013; Ashwood et al., 2017).

The aim of this mesocosm experiment was to investigate the interaction effects between earthworms, trees and soil quality after CGW addition, in order to inform future land restoration activities. The experimental design is based upon the study done by Rajapaksha et al. (2014), which successfully demonstrated a beneficial earthworm-tree interaction between native UK earthworms and an exotic eucalypt tree species. Specific objectives of the present study were to: (i) measure the effect of composted green waste (CGW) and earthworm activity on tree growth and nutrient uptake in reclaimed soil; (ii) investigate the effects of CGW and tree species on earthworm community density in reclaimed soil; (iii) assess the effects of CGW, tree species, earthworm activity and their interactions, on reclaimed soil carbon and nutrient status.

\section{Materials and Methods}




\subsection{Study site and experimental design}

The experiment was located at the Forest Research Headley Nursery Enclosure, Hampshire (Nat. Grid Ref: TQ 54929 84214), previously used for similar experiments (McKay et al., 1999; Moffat, 2000; Broadmeadow et al., 2005; Rajapaksha et al., 2014). It utilised a planting-tube mesocosm technique, similar to that employed by Rajapaksha et al. (2014). The mesocosms consisted of $0.25 \mathrm{~m}$ diameter, $3 \mathrm{~mm}$ thick PVC tubes cut to $0.6 \mathrm{~m}$ lengths. The base of each tube was covered with fine mesh ( $1 \mathrm{~mm}$, supplied by Amari Plastics) to prevent earthworm ingress/egress. Earthworms were further confined inside the open-top mesocosms through the application of two unbroken strips of adhesive plastic hook ('velcro') tape applied to the inside of the tubes, following the design of Lubbers and van Groenigen (2013). Tubes were buried in the ground to $0.4 \mathrm{~m}$ depth, with $0.2 \mathrm{~m}$ protruding above ground level. This technique allows removal of whole soil/root system from the tube at termination of the experiment and permits detailed examination for desired soil depths and has been successfully used for tree root experiments (Bending and Moffat, 1997) and tree growth/earthworm interaction experiments (Rajapaksha et al., 2014). Each tube was filled to $0.4 \mathrm{~m}$ depth with a soil treatment, and a tree was planted in the middle of each tube (detail in 2.2.). The experiment began in June 2014 and ran until July 2015.

Figure 1 shows the layout of tubes within the experimental plot, which consisted of five blocks, each containing a randomised placement of 9 planting tubes ( 4 treatments $X 2$ tree species, and 1 soilonly control). Each block contained a representative of each tree species in all four treatment combinations, and a tree-free control tube, which contained de-faunated reclaimed soil only, to account for the effect of tree species alone on soil parameters. Each of the nine tree-treatment combinations had five replicates, totalling 45 tubes in this experiment. Each block was separated by a 3-m buffer zone, and within the blocks, each planting tube was separated by $1.5 \mathrm{~m}$. The wider experimental plot itself was homogenous and each planting tube was separated from the surrounding soil. As such, each tube acted as an individual experimental unit (e.g. replicate), irrelevant of location on-site. The perimeter of the experiment location was surrounded by an electrified rabbit-proof fence to prevent damage to trees by small herbivorous mammals. Following tree planting, a continuous drip irrigation system was applied to each tube to maintain soil moisture level at $25-30 \%$ for optimal tree growth (Figure 2).

\section{[INSERT FIGURE 1]}

A single Prenart Super Quartz soil water sampler (PTFE suction cup lysimeters, $25 \mathrm{~mm}$ diameter, 95 $\mathrm{mm}$ length) was installed in each tube, within the upper $0.1 \mathrm{~m}$ of the soil profile, to allow for soil solution samples to be taken by connecting it to a vacuumed bottle. These were subsequently found to be unable to remove sufficient soil water samples for chemical analysis, despite soil in tubes being kept sufficiently moist through irrigation (perhaps due to high clay and stone fraction of reclaimed soil media preventing good contact) and so this method of sampling was abandoned.

\section{[INSERT FIGURE 2]}

\subsection{Experimental treatments}

This experiment employed four treatment combinations: no treatment (control); CGW addition only; mixed-species earthworm addition only; and CGW and mixed-species earthworm addition. For CGWtreated tubes, the soil included incorporation of screened 0-25mm PAS 100 "Soil Improver" grade

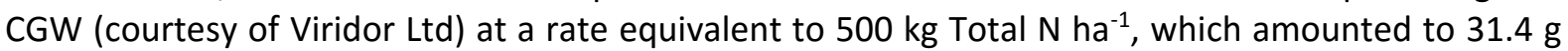

tube $^{-1}$. This amendment rate was chosen to reflect the legal limit set by Nitrates Directive for Nitrate Vulnerable Zones (NVZs), following guidance of Taylor (1991) and Bending et al. (1999). A full summary of CGW nutrient content is provided in Table 1.

\section{[INSERT TABLE 1]}


Fresh reclaimed soil was collected from Ingrebourne Hill Community Woodland, a 54-ha area of reclaimed land in Rainham, Essex, UK (Nat. Grid Ref: TQ 52572 83192). The soils at Ingrebourne Hill comprise generally of sandy clay loam materials, with a high stone content (Heaven and Richardson, 2007). Metal contents were within the UK soil guideline values for non-residential uses, and not considered to be at levels harmful to fauna (Doick and Willoughby, 2011). Further soil data are provided in Table 2. Following removal from the site, soil was initially de-faunated in bulk by placement into $30 \mathrm{I}$ sealed plastic containers, and stored at $-5^{\circ} \mathrm{C}$ for 7 days to destroy native earthworms and other potential competitors/predators (Butt, 2011). It was then allowed to thaw before being fully homogenised using a cement-mixer, which was cleaned thoroughly before use, and some disposable soil initially run though to collect any potential contaminants. The homogenised soil was placed into clean tonne soil bags ready for addition to mesocosms. The volume of soil was measured to replicate the $1.06 \mathrm{~g} \mathrm{~cm}^{-3}$ mean bulk density observed at Ingrebourne Hill (Ashwood, 2016) (23.3 kg wet soil was added per tube).

\section{[INSERT TABLE 2]}

Soils were left to settle in the mesocosms for one week prior to tree planting. One-year-old roottrainer seedlings (the standard age for trees planted in the field) of Norway maple (Acer platanoides) and Italian alder (Alnus cordata) were obtained from a local nursery, planted in the mesocosms and left for 2 weeks before earthworm introduction. This experiment investigated two earthworm species: Aporrectodea longa and Allolobophora chlorotica, which represent ecological groups considered more beneficial to soil development (anecic and endogeic, respectively, sensu Bouché, 1977). These earthworm species have previously shown tolerance for the soil conditions typically presented by reclaimed landfill (Butt and Lowe, 2004; Butt, 2008; Ashwood et al., 2017). All earthworms were collected from pasture at Walton Hall Farm, Preston, UK (Nat. Grid Ref: SD 55050 28100), via digging and hand-sorting of soil, then transferred and stored in fresh soil collected from Ingrebourne Hill, before transporting to Headley Nursery. For mesocosms receiving an earthworm treatment $(n=20)$, introduction was a mixed culture of $A$. longa $(n=5)$ and $A$. chlorotica $(n=10)$. These numbers were based on recorded field densities at an experiment at Ingrebourne Hill, Essex, following inoculation with $A$. longa (Ashwood, 2016), and in keeping with numbers used by Rajapaksha et al. (2014). The A. chlorotica used in this experiment were of mixed pink and green morphs (Lowe and Butt, 2008), however all were selected to be of similar biomass, and morph was not considered to be a limiting factor as reproductive output was not one of the measurements.

\subsection{Experimental sampling}

Visual surveying of all tubes was undertaken weekly during autumn, with the number of leaves of both tree species on the soil surface recorded per tube. After 12 months, the mesocosms were carefully dug out of the ground, ensuring that the fine mesh still covered the base and kept the experimental mesocosm unit intact. Mesocosms (containing soils and trees) were transported to an on-site workshop for processing, where each tube was opened using a portable circular saw to allow access to the undisturbed soil column inside (Figure 3 ). The tree height and ground-line diameter was recorded. The above-ground section of the tree was removed by severing at the ground-line, and apportioned into three sub-samples for analysis; main stem; branches; and leaves. The soil column and plant roots were divided into two sections; shallow ( 0 to $0.2 \mathrm{~m}$ depth) and deep (0.2 to $0.4 \mathrm{~m}$ depth). Earthworms were hand-sorted from the soil in each section and numbers recorded. These were preserved in $4 \%$ formaldehyde solution for identification in the laboratory, following the key of Sims and Gerard (1999).

\section{[INSERT FIGURE 3]}

Both the shallow and deep soil sections were divided into bulk and rhizosphere (root-attached) soil. Rhizosphere soil was obtained by shaking the roots from each section inside a clean plastic sample 
bag. Live root samples were then divided into the two sub-categories of main root (stump and roots $>2 \mathrm{~mm}$ diameter), and fine roots ( $<2 \mathrm{~mm}$ diameter) from each soil section. Before chemical analysis, all root samples were jet-washed through a fine sieve $(0.5 \mathrm{~mm})$ to remove attached soil. Plant and soil samples were processed at Forest Research Laboratory Services at Alice Holt Lodge, Farnham, UK. A random sample of 100 leaves was taken from each tree to have Specific Leaf Area (SLA) $\left(\mathrm{cm}^{2} \mathrm{~g}^{-}\right.$ $\left.{ }^{1}\right)$ per dry weight calculated, following European forest monitoring protocols (Pitman et al., 2010). This was conducted using a Delta-T Area Meter (MK2) linked via video camera to a Delta-T Conveyor Belt Unit Area Measurement System (Delta-T devices, Cambridge, England). All plant material was then oven-dried at $70^{\circ} \mathrm{C}$ for $48 \mathrm{~h}$, the dry biomass recorded and samples analysed chemically. Plant and soil samples had total organic $\mathrm{C}$ and $\mathrm{N}$ determined using a CN Elemental Analyser (Carlo Erba (THERMO), FLASH EA 1112 Series), and major elements (P, K, Ca and Mg) analysed after sulphuric acid digestion and inductively coupled plasma-optical emission spectrophotometry (ICP-OES) analysis, soil moisture content analysed by oven drying at $105^{\circ} \mathrm{C}$ for 24 hours, and soil pH was measured in 1:2.5 soil/water suspension. The $1 \mathrm{M} \mathrm{KCL}$-extraction method was used following the procedure described in MAFF (1986) on fresh soil to provide filtered samples for determining levels of inorganic "available" nitrogen, e.g. $\mathrm{NO}_{3}{ }^{-} \mathrm{N}$ and $\mathrm{NH}_{4}{ }^{+}-\mathrm{N}$ by colorimeter analysis.

\subsection{Measurements and statistical analysis}

Earthworm density and community change were measured to assess the effects of tree species and soil treatment. The effect of soil treatment and/or earthworm activity on tree growth and health were measured via data on tree survival, tree nutrient status, SLA, ground-line diameter, and above and below-ground tree biomass. Bulk and rhizosphere soil samples were chemically analysed for soil $\mathrm{pH}$, total organic $\mathrm{C}$ and $\mathrm{N}$, major elements and soil moisture content to investigate the effect of tree, CGW addition and earthworm activity on soil quality. Data were first tested for normality using the Shapiro-Wilk test, which is suited to the sample size in this experiment $(n=5)$. As all data for each species and treatment had a normal distribution, the data were analysed using one and two-way analysis of variance (ANOVA), with the Tukey-Kramer post-hoc multiple comparison test applied to significant treatment interactions. Analysis of baseline soil data were performed using a 2-sample student's $t$-test. Statistical analysis was performed using the statistical software GenStat (Release 16.2).

\section{Results}

3.1. The effects of earthworm activity and CGW addition on tree survival, growth, biomass and nutrient status

Both tree species achieved $100 \%$ survival across all treatments. A. cordata clearly demonstrated greater growth than $A$. platanoides throughout the experiment, across all treatments. At the start of the experiment there was no significant difference in individual height or diameter of trees between treatments, for each tree species. At the termination of the experiment, no effect on A. cordata height and ground-line diameter was found under the CGW or earthworm treatments, or combination of the two (Figures 4 and 5). A. platanoides showed greater height (ANOVA, $d f=3, F=$ $3.60, p<0.05$ ), but not diameter, under the earthworm plus CGW treatment than the control group for this species (Figure 4).

\section{[INSERT FIGURE 4]}

\section{[INSERT FIGURE 5]}

No effects of treatment were found on the biomass of either tree species. Stem C content (\%) of $A$. cordata was increased in both earthworm treatment and earthworm plus CGW treatment (mean \pm SE $=50.23 \pm 0.12$ and $50.24 \pm 0.22$, respectively) compared with the earthworm-free control group (mean $\pm \mathrm{SE}=49.36 \pm 0.01$ ) (ANOVA, $\mathrm{df}=3, F=8.75, \mathrm{p}<0.001$ ) in the upper soil level, fine root $\mathrm{Ca}$ 
levels (\%) of $A$. cordata were higher (ANOVA, $\mathrm{df}=3, F=3.82, \mathrm{p}<0.05$ ) in the earthworm-only treatment (mean $\pm \mathrm{SE}=1.69 \pm 0.06$ ) than the $\mathrm{CGW}$-only treatment (mean $\pm \mathrm{SE}=1.41 \pm 0.08$ ). The average $\mathrm{C}$ : $\mathrm{N}$ ratios for $A$. cordata and $A$. platanoides leaves was 19.4 and 37.5 , respectively. No treatment effect on the Specific Leaf Area (SLA) measurements of either tree species was found.

\subsection{The effects of tree and soil treatments on earthworm populations}

At termination of the experiment after 12 months, there was significantly higher A. chlorotica density in mesocosms containing $A$. platanoides with CGW treatment than all other treatments and tree species tubes in the experiment (ANOVA, $d f=3, F=5.75, p=0.002$ ). There were no significant differences in $A$. longa density between tree species or treatments (Table 3). Under A. cordata, $A$. chlorotica population density reduced by $78 \%$ in both treatments, and by $50 \%$ and $82 \%$ under $A$. platanoides with and without CGW, respectively. Comparatively, A. longa experienced higher survival rates, with an average reduction in final population density of $24 \%$ and $8 \%$ under $A$. cordata with and without CGW, respectively. Under $A$. platanoides, $A$. longa density was reduced by $36 \%$ and $32 \%$ under CGW and earthworm only treatment, respectively.

\section{[INSERT TABLE 3]}

At termination of the experiment, some of the earthworm-free control tubes were found to contain low numbers of $A$. longa and $A$. chlorotica. The mean $( \pm \mathrm{SE})$ density of $A$. longa per control tube was $0.5( \pm 0.3)$ and $0.7( \pm 0.3)$ for $A$. cordata, and A. platanoides, respectively. A. chlorotica mean density $( \pm \mathrm{SE})$ per control tube was $0.6( \pm 0.4)$ and $0.2( \pm 0.1)$ for $A$. cordata and $A$. platanoides, respectively. No other earthworm species were found in the earthworm-control tubes in the experiment, and no earthworms were recovered in the tree-free control tubes. A total of 3 individuals of $L$. rubellus were found within two tubes (containing CGW plus earthworm treatment) during sampling, representing a mean density $( \pm S E)$ of $0.03( \pm 0.07)$ per tube.

\subsection{Soil responses to earthworm activity, CGW addition and tree species presence}

At the start of the experiment, there was little variability $(C V<10 \%)$ in soil chemical parameters between the sub-samples of CGW-free soil (Table 4, and Table $V$ in supplementary material). CGW addition led to increased soil $\mathrm{pH}(\mathrm{p}<0.05)$, and higher total $\mathrm{N}$, organic $\mathrm{C}$, organic matter content and $\mathrm{PO}_{4}{ }^{3-}(\mathrm{p}<0.001)$. Addition of CGW was associated with a reduction in soil Ca content $(\mathrm{p}<0.05), \mathrm{C}: \mathrm{N}$ ratio, $\mathrm{NO}_{3}{ }^{-}$and $\mathrm{SO}_{4}{ }^{2-}(p<0.001)$ compared with baseline soils.

\section{[INSERT TABLE 4]}

At termination of the experiment, soil chemistry results for bulk soil under trees in the CGW-free and earthworm-free controls showed several effects of tree species, compared with the tree-free control soils (Table 5 , and Table VI in supplementary material). Under $A$. cordata, there was higher $(p<0.05)$ soil organic $C(\%)$ and organic matter $(\%)$, and lower $(p<0.001)$ soil moisture content $(\%)$, and plant nutrients $\mathrm{K}, \mathrm{Mg}$, and $\mathrm{PO}_{4}{ }^{3-}(\mathrm{mg} / \mathrm{kg})(\mathrm{p}<0.05)$. Bulk soil under $A$. platanoides was not different to the control soil, except in moisture content (\%), which was lower than the control (ANOVA, df $=1, F=$ 7.43, $\mathrm{p}<0.001$ ), but also higher (ANOVA, $\mathrm{df}=1, F=8.70, \mathrm{p}<0.001$ ) than under $A$. cordata.

\section{[INSERT TABLE 5]}

Underneath both tree species, several effects were observed on bulk and rhizosphere soil quality due to CGW and earthworm addition. In all cases, deeper soil sections (0.2-0.4 $\mathrm{m}$ ) did not provide sufficient rhizosphere (root-attached soil) for performance of chemical analysis. $A$. cordata bulk soil in the shallow $0.2 \mathrm{~m}$ soil section had a higher $(p<0.05)$ soil organic carbon and organic matter content in the CGW-earthworm combination treatment than in the tree-free control shallow soil section (Tables I and VII, supplementary material). Total $N$ was higher $(p<0.001)$ in soils receiving treatments containing CGW than control soil. Bulk soil C:N ratio was higher in the earthworm only 
treatment $(\mathrm{p}<0.05)$ than the $\mathrm{CGW}$-only treatment. Soil moisture content $(\%)$ and $\mathrm{K}$ and $\mathrm{NO}_{3}{ }^{-}$content was higher $(p<0.001)$ in the tree-free control, compared with the control and the earthworm-only treatments under $A$. cordata. In the $0.2 \mathrm{~m}$ rhizosphere soil, the only differences were in the CGWonly treatment, which had the lowest $\mathrm{C}: \mathrm{N}$ ratio (ANOVA, $\mathrm{df}=3, F=8.31, \mathrm{p}<0.001$ ) and highest content of $\mathrm{PO}_{4}{ }^{3-}$ (ANOVA, $\left.\mathrm{df}=3, \mathrm{~F}=3.45, \mathrm{p}<0.05\right)$. In the 0.2-0.4 $\mathrm{m}$ deep soil under $A$. cordata, organic $\mathrm{C}$, organic matter and total $\mathrm{N}$ were higher $(\mathrm{p}<0.001)$ under $\mathrm{CGW}$-only and earthworm plus CGW combination treatments.

A. platanoides bulk soil in the shallow $0.2 \mathrm{~m}$ soil section had a higher total $\mathrm{N}$, soil organic carbon and organic matter content in both the CGW-only and CGW-earthworm combination treatments than the controls and earthworm-only treatments $(p<0.001)$. Under the CGW-only treatment, levels of $K$, $\mathrm{NH}_{4}{ }^{+}$and $\mathrm{PO}_{4}{ }^{3-}$ were higher $(\mathrm{p}<0.05)$ than control and earthworm-only tubes (Tables II and $\mathrm{VIII}$, supplementary material). Bulk soil, in both the shallow and deep sections, had higher C:N ratio in earthworm-only treatment than the tubes receiving CGW treatments. In the 0.2-0.4 m deep soil under $A$. platanoides, soil total $\mathrm{N}$, organic matter and $\mathrm{PO}_{4}{ }^{3-}$ were higher under the and earthworm plus CGW combination treatments $(p<0.05)$.

\section{Discussion}

4.1. The effects of CGW and earthworm activity on tree growth and nutrient uptake in reclaimed soil

After 12 months in the mesocosms, A. cordata outperformed A. platanoides in growth, across all treatments. In a comparable field experiment, Foot et al. (2003) found that under a similar application rate of CGW to capped landfill sites, $A$. cordata significantly outperformed sycamore $(A$. pseudoplatanus). This was attributed to greater availability of $\mathrm{N}$ to the nitrogen-fixing alder species, through its association with Frankia bacterium, and the $A$. cordata in the experiment presented here also showed development of root nodules. In the current study, a positive synergistic effect of CGW and earthworm activity was observed on $A$. platanoides height, final ground-line diameter and percentage diameter increase. This is in direct contrast to the findings of Ashwood (2016), who found no effect of CGW or earthworm addition on A. platanoides growth rates in reclaimed soils in a field experiment, which could be due to drought stress in comparison to soil moisture controlled mesocosms in this study. This is can be explained as an extension of Leibig's Law of the Minimum (Von Liebig, 1840), which states that the fertility of a soil for a particular plant is determined by the availability of the limiting nutrient. In this case, the improved growth response of $A$. platanoides was due to the removal of a limiting factor - soil moisture - rather than addition of a limiting nutrient (Gea-Izquierdo et al., 2009). With adequate soil moisture, this tree species was subsequently able to demonstrate a response to the soil nutrient increases by CGW addition and earthworm activity. The significantly greater density of $A$. chlorotica found under this tree species may also have contributed to such benefits (Edwards, 2004).

No significant effect of CGW or earthworm treatments was found for $A$. cordata height, ground-line diameter or biomass, similar to Foot et al. (2003). In field conditions, this species has demonstrated high drought tolerance (Ashwood, 2016) and is not nitrogen-limited; therefore additional nutrient supply may not increase growth of these species as much as for nutrient-limited trees. It is therefore likely that earthworm processing of decomposing organic matter is of less benefit to such hardy and $\mathrm{N}$-fixing trees species.

In our experiment, earthworm presence significantly increased the $C$ content of $A$. cordata stem and Ca levels in fine roots ( $0-0.2 \mathrm{~m}$ soil) under the earthworm only treatment compared with the CGWonly treatment. Similarly, Wolters and Stickan (1991) found higher C content in stems of beech (Fagus sylvatica) seedlings, when grown in forest soils with an individual Octolasion lacteum (an endogeic, geophagous earthworm species), compared with controls. The mechanisms behind earthworm-induced increases in plant growth and nutrient acquisition are generally accepted to be 
enhanced organic matter decomposition and nutrient mineralisation (Marshall, 1971; Haimi et al., 1992).

\subsection{The effects of CGW and tree species on earthworm populations}

In this experiment, there was similar density of $A$. longa across all mesocosms, irrespective of treatment or tree species. There was, however, a significantly greater population of $A$. cholorotica under $A$. platanoides with CGW present. In natural systems $A$. chlorotica (an endogeic species) dwells within the rhizosphere and forms close associations with the root systems of plants (Sims and Gerard, 1999). Therefore, root chemistry might be expected to affect this earthworm species through root exudates, or by modifying local soil pH (Dakora and Phillips, 2002; Rajapaksha et al., 2014) although no such effects on soil were observed in our study. A. longa population density experienced a mean reduction of $20 \%$ during the experiment, and A. chlorotica experienced a $50-$ $80 \%$ reduction in population density. It is notable that such relatively low earthworm survival rates still enabled clear effects of earthworm activity to be observed. Research indicates that earthwormmediated improvements in soil nutrient availability, and subsequent benefits to plant growth, are likely to be greater in nutrient-poor soils (Jana et al., 2010). In higher quality soils, plants may be less affected by nutrient limitation and hence any benefits from earthworm activity harder to detect (Brown et al., 2004). Whilst earthworm survival rates were relatively low, the final population densities of earthworms in the mesocosm tubes (a minimum of $64 \mathrm{~m}^{-2}$ and $36 \mathrm{~m}^{-2}$, for A. longa and A. chlorotica, respectively) are not unusual when compared with those commonly found on young reclaimed landfill sites. For example, Pizl (2001) recorded an earthworm density of $66.7 \mathrm{~m}^{-2}$ after one year on an afforested colliery spoil in Czech Republic, and Judd and Mason (1995) recorded approximately $80 \mathrm{~m}^{-2}$ on a four year old reclaimed landfill site in the UK.

Under laboratory conditions, the generation time of both species (cocoon to mature adult) fits within the twelve month timeframe of the present experiment (Lowe and Butt, 2005), indicating that soil conditions and/or food availability may not have been suited to earthworm reproduction. However, similar mortality rates observed by Rajapaksha et al. (2014) in a better quality soil in mesocosms of the same size suggests that earthworm mortality may have been influenced by stress from addition to mesocosms, rather than specific soil conditions. Under field conditions, CGW has been shown to support populations of both $A$. chlorotica and $A$. longa in reclaimed soil for at least 2 years following surface application (Lowe and Butt, 2004). Finding conflicting earthworm survival results between a pot and a field experiment, Butt (1999a) suggested that for some organic wastes, pot experiments may be an unreliable indicator of earthworm performance in natural systems; our results indicate that this may indeed be the case for CGW. He attributed this to issues such as sterilisation of soil and therefore absence of interaction with plants and fauna, and a build-up of ammonia and salts, to which earthworms are sensitive. It is also possible that longer experimental duration may have enabled earthworm populations to recover following seasonal additions of organic matter from leaf litter once CGW has been fully utilised by earthworms, as the foliar material of both tree species has been shown to be palatable to these earthworm species (Ashwood et al., 2017).

4.3. The effects of CGW, tree species, earthworm activity and their interactions, on reclaimed soil carbon and nutrient status

CGW addition affected bulk soil carbon and nutrient levels with significantly higher shallow 0-0.2 m soil organic carbon (\%) and organic matter (\%) in the CGW-earthworm combination treatment under both tree species, compared to the CGW-only treatment. This may be explained by leaf litter accumulation in the soil through earthworm activity. Bohlen and Edwards (1995) found that earthworms increased the amounts of extractable $\mathrm{N}$ and $\mathrm{NH}_{4}{ }^{+}$from manure and legume organic waste treatments. However, in our study, under both tree species the levels of soil total $\mathrm{N}$ and $\mathrm{NH}_{4}{ }^{+}$ were significantly higher in the CGW-only treatment. Interestingly, this suggests that earthworm 
activity did not increase the level of extractable $\mathrm{NH}_{4}{ }^{+}$released from CGW beyond typical CGW decomposition rates, or this was consumed by the earthworms. Since soil $\mathrm{pH}$ was high, these may also have been rapidly converted to $\mathrm{NO}_{3}{ }^{-}$form or $\mathrm{NH}_{4}{ }^{+}$bound to clay lattices in the soil. Earthworm activity was associated with significantly higher $\mathrm{C}: \mathrm{N}$ ratio in the shallow section bulk soil under both tree species, and the deep bulk soil under A. platanoides, compared with earthworm-free controls. This is likely due to earthworm activity distributing organic matter from surface leaf litter into the deep soil level (Lowe and Butt, 2003) and high utilisation of available N. For example, Welke and Parkinson (2003) found that lower horizon mineral soil contained significantly higher organic matter content in the presence of the endogeic (shallow burrowing) earthworm species Aporrectodea trapezoides.

Tree roots of both species increased the levels of $\mathrm{C}, \mathrm{N}$, and availability of cations in the rhizosphere compared with bulk soil, and reduced $\mathrm{pH}$ and the availability of $\mathrm{K}^{+}$and anions. Increases in organic carbon are likely due to root exudation of organic compounds and root turnover (Day et al., 2010; Lukac and Godbold, 2011). Furthermore, trees can influence rhizosphere nutrient supply through biological $\mathrm{N}$ fixation (e.g. by alder species), and through the extraction of nutrients, especially nitrate; with subsequent effects on $\mathrm{pH}$ and the mobility of other chemicals, e.g. anions and cations (Day et al., 2010).

\section{Conclusions}

This study provides evidence that CGW can improve tree growth under the limiting conditions found in reclaimed soils, and that earthworm activity can provide a positive synergistic effect on this. However, this may not be the case for tree species which are not limited by nutrient availability or abiotic stress, e.g. alder species. For tree species such as these, simple measures such as irrigation may provide the necessary conditions for their growth and survival. Earthworm population densities showed that CGW addition may serve as a suitable source of organic matter to support earthworms on reclaimed sites. However, a higher rate of CGW application than used in this study is likely to better support earthworm populations and enhance the associated benefits to soil quality and tree growth. Survival rates also indicated that $A$. longa was better suited than $A$. chlorotica to the soil materials used. CGW was shown to significantly improve the reclaimed soil through increased levels of organic carbon and essential plant macro-nutrients.

Future studies would benefit from a longer duration, e.g. minimum of 24 months, to allow tree and earthworm biomass and soil data to reflect any longer-term effects of organic waste application. Additionally, although the CGW application rate used in this study was reflective of legal limits, studies investigating higher application rates of CGW and other organic waste materials and mixtures may identify further opportunities to improve sustainable woodland and earthworm population establishment on reclaimed land.

\section{Acknowledgements}

The authors would like to thank the Forestry Commission England's Thames Beat team for providing funding and resources to support this research. We are grateful to Viridor Ltd for supplying us with composted green waste. 


\section{References}

Ashwood, F. (2016). Woodland Restoration on Landfill Sites: Earthworm Activity and Ecosystem Service Provision. PhD Thesis, University of Central Lancashire.

Ashwood, F., Butt, K. R., Doick, K. J. and Vanguelova, E. I. (2017). Investigating tree foliar preference by the earthworms Aporrectodea longa and Allolobophora chlorotica in reclaimed and loam soil. Applied Soil Ecology, 110, p.109-117.

Ashwood, F. E., Doick, K. J., Atkinson, G. E. and Chenoweth, J. (2014). Under-utilisation of organic wastes during brownfield regeneration to community woodland: tackling the barriers. Waste Management \& Research, 32 (1), p.49-55.

Bending, N. A. D. and Moffat, A. J. (1997). Tree Establishment on Landfill Sites. Research and updated guidance. Edinburgh: Forestry Commission.

Blouin, M., Hodson, M. E., Delgado, E. A., Baker, G., Brussaard, L., Butt, K. R., Dai, J., Dendooven, L., Peres, G., Tondoh, J. E., Cluzeau, D. and Brun, J.-J. (2013). A review of earthworm impact on soil function and ecosystem services. European Journal of Soil Science, 64 (2), p.161-182.

Bohlen, P. J. and Edwards, C. A. (1995). Earthworm effects on N dynamics and soil respiration in microcosms receiving organic and inorganic nutrients. Soil Biology and Biochemistry, 27 (3), p.341-348.

Bouché, M. B. (1977). Strategies lombriciennes. In: Lohm, U. and Person, T. (eds.), Organisms as components of ecosystems, Stockholm: Ecological Bulletin, p.122-132.

Broadmeadow, M. S. J., Ray, D. and Samuel, C. J. A. (2005). Climate change and the future for broadleaved tree species in Britain. Forestry, 78 (2), p.145-161.

Brown, G. G., Edwards, C. A. and Brussaard, L. (2004). How earthworms affect plant growth: burrowing into the mechanisms. In: Edwards, C. A. (ed.), Earthworm Ecology, Boca Raton: CRC Press, p.13-49.

Butt, K. R. (1999a). Effects of thermally dried sewage granules on earthworms and vegetation during pot and field trials. Bioresource technology, 67, p.149-154.

Butt, K. R. (1999b). Inoculation of earthworms into reclaimed soils: the UK experience. Land Degradation \& Development, 10 (6), p.565-575.

Butt, K. R. (2008). Earthworms in Soil Restoration: Lessons Learned from United Kingdom Case Studies of Land Reclamation. Restoration Ecology, 16, p.637-641.

Butt, K. R. (2011). The earthworm inoculation unit technique: development and use in soil improvement over two decades. In: Karaca, A. (ed.), Biology of Earthworms, Berlin: SpringerVerlag, p.87-105.

Butt, K. R. and Lowe, C. N. (2004). Anthropic influences on earthworm distribution, Isle of Rum National Nature Reserve, Scotland. European journal of soil biology, 40 (2), p.63-72.

Dakora, F. D. and Phillips, D. A. (2002). Root exudates as mediators of mineral acquisition in low-nutrient environments. Plant and Soil, 245 (1), p.35-47.

Day, S. D., Wiseman, P. E., Dickinson, S. B. and Harris, J. R. (2010). Tree Root Ecology in the Urban Environment and Implications for a Sustainable Rhizosphere. Arboriculture \& Urban 
Forestry, 36 (September), p.193-205.

Doick, K. J. and Willoughby, I. (2011). Investigation into low tree establishment rates at Ingrebourne Hill's phase IIA restoration area. Farnham: Forest Research.

Edwards, C. A. (2004). Earthworm ecology. Boca Raton, FL: CRC Press.

Foot, K. J., Hislop, M. and McNeilly, S. (2003). The effect of composted green waste on tree establishment on landfill. In: Moore, H. M., Fox, H. R. and Elliot, S. (eds.), Land Reclamation Extending the Boundaries, Lisse: AA Balkema, p.213-221.

Forest Research. (2011). Short Rotation Forestry: Review of Growth and Environmental Impacts.

Forest Research. (2015). Best Practice Guidance for Land Regeneration. Farnham: Forest Research.

Gea-Izquierdo, G., Montero, G. and Canellas, I. (2009). Changes in limiting resources determine spatio-temporal variability in tree-grass interactions. Agroforest Syst (2009), 76, p.375-387.

Haimi, J., Huhta, V. and Boucelham, M. (1992). Growth increase of birch seedlings under the influence of earthworms - A laboratory study. Soil Biology and Biochemistry, 24 (12), p.1525-1528.

Heaven, F. W. and Richardson, G. R. (2007). Soil Investigation at Ingrebourne Valley, Phase IIA, Rainham. Derby: Land Research Associates.

Hibberd, B. G. (1986). Forestry Commission Handbook 5: Urban Forestry Practice. London: HMSO.

Jana, U., Barot, S., Blouin, M., Lavelle, P., Laffray, D. and Repellin, A. (2010). Earthworms influence the production of above-and belowground biomass and the expression of genes involved in cell proliferation and stress responses in Arabidopsis thaliana. Soil Biology and Biochemistry, 42 (2), p.244-252.

Judd, K. W. and Mason, C. F. (1995). Earthworm populations of a restored landfill site. Pedobiologia, 39, p.107-115.

Kibblewhite, M. G., Ritz, K. and Swift, M. J. (2008). Soil health in agricultural systems. Philosophical transactions of the Royal Society of London. Series B, Biological sciences, 363, p.685-701.

Larson, E. R., Kipfmueller, K. F., Hale, C. M., Frelich, L. E. and Reich, P. B. (2010). Tree rings detect earthworm invasions and their effects in northern Hardwood forests. Biological Invasions, 12 (5), p.1053-1066.

Von Liebig, J. (1840). Chemistry in its Application to Agriculture and Physiology. London: Taylor and Walton.

Lowe, C. N. and Butt, K. R. (2002). Influence of organic matter on earthworm production and behaviour: a laboratory-based approach with applications for soil restoration. European Journal of Soil Biology, 38 (2), p.173-176.

Lowe, C. N. and Butt, K. R. (2003). Influence of food particle size on inter- and intra-specific interactions of Allolobophora chlorotica (Savigny) and Lumbricus terrestris. Pedobiologia, 47 (5-6), p.574-577. 
Lowe, C. N. and Butt, K. R. (2004). Use of Composted Green Waste (CGW) to improve landfill cap quality through the agency of earthworms. Proceedings of Waste 2004: Integrated Waste Management \& Pollution Control: Policy \& Practice, Research \& Solutions, p.853-862.

Lowe, C. N. and Butt, K. R. (2005). Culture techniques for soil dwelling earthworms: A review. Pedobiologia, 49 (5), p.401-413.

Lowe, C. N. and Butt, K. R. (2008). Allolobophora chlorotica (Savigny, 1826): Evidence for classification as two separate species. Pedobiologia, 52 (2), p.81-84.

Lubbers, I. M. and van Groenigen, J. W. (2013). A simple and effective method to keep earthworms confined to open-top mesocosms. Applied Soil Ecology, 64, p.190-193.

Lukac, M. and Godbold, D. L. (2011). Soil ecology in northern forests: a belowground view of a changing world. Cambridge: Cambridge University Press.

Marshall, V. G. (1971). Effects of soil arthropods and earthworms on the growth of Black Spruce. Annals of Zoology and Ecology, 7, p.109-118.

McKay, H. M., Jinks, R. L. and McEvoy, C. (1999). The effect of desiccation and roughhandling on the survival and early growth of ash, beech, birch and oak seedlings. Annals of Forest Science, 56 (5), p.391-402.

Ministry of Agriculture, Fisheries and Food. (1986). The Analysis of Agricultural Materials. Third Edit. London: HMSO.

Moffat, A. J. (2000). Effects of inoculation with Frankia on the growth and nutrition of alder species and interplanted Japanese larch on restored mineral workings. Forestry, 73 (3), p.215-223.

Moffat, A. J. (2006). Use of Sewage Sludges and Composts in Forestry. Forestry Commission Information Note 79, p.1-12.

Moffat, A. J., Hutchings, T. R., Tubby, I., Butt, K. R. and Lowe, C. N. (2008). Experimental woodland establishment on brick clays in southern England. Land Contamination \& Reclamation, 16 (3), p.181-190.

Muys, B., Beckers, G., Nachtergale, L., Lust, N., Merckx, R. and Granval, P. (2003). Mediumterm evaluation of a forest soil restoration trial combining tree species change, fertilisation and earthworm introduction. Pedobiologia, 47, p.772-783.

Muys, B., Lust, N. and Granval, P. (1992). Effects of grassland afforestation with different tree species on earthworm communities, litter decomposition and nutrient status. Soil Biology and Biochemistry, 24 (12), p.1459-1466.

Nason, M., Williamson, J., Tandy, S., Christou, M., Jones, D. and Healey, J. (2007). Using organic wastes and composts to remediate and restore land: best practice manual. Bangor: School of the Environment and Natural Resources, Bangor University.

Piearce, T. G. and Boone, G. C. (1998). Responses of invertebrates to paper sludge application to soil. Applied Soil Ecology, 9, p.393-397.

Pigott, C. D. (1989). The growth of lime (Tilia cordata) in an experimental plantation and its influence on soil development and vegetation. Quarterly Journal of Forestry, 83 (1), p.14-24. Pitman, R., Bastrup-Birk, A., Breda, N. and Rautio, P. (2010). Sampling and Analysis of 
Litterfall. In: Manual on methods and criteria for harmonized sampling, assessment, monitoring and analysis of the effects of air pollution on forests, Hamburg: UNECE ICP Forests Programme Co-ordinating Centre, p.16.

Pizl, V. (2001). Earthworm succession in afforested colliery spoil heaps in the Sokolov region, Czech Republic. Restoration Ecology, 9 (4), p.359-364.

Rajapaksha, N. S. S., Butt, K. R., Vanguelova, E. I. and Moffat, A. J. (2013). Earthworm selection of Short Rotation Forestry leaf litter assessed through preference testing and direct observation. Soil Biology and Biochemistry, 67, p.12-19.

Rajapaksha, N. S. S., Butt, K. R., Vanguelova, E. I. and Moffat, A. J. (2014). Short rotation forestry--Earthworm interactions: A field based mesocosm experiment. Applied Soil Ecology, 76, p.52-59.

Reich, P. B., Oleksyn, J., Modrzynski, J., Mrozinski, P., Hobbie, S. E., Eissenstat, D. M., Chorover, J., Chadwick, O. A., Hale, C. M. and Tjoelker, M. G. (2005). Linking litter calcium, earthworms and soil properties: A common garden test with 14 tree species. Ecology Letters, 8 (8), p.811-818.

Scullion, J. (1992). Re-establishing life in restored topsoils. Land Degradation \& Development, 3, p.161-168.

Sims, R. W. and Gerard, B. M. (1999). Earthworms: notes for the identification of British species. No. 31. Linnean Society of London and the Estuarine and Coastal Sciences Association.

Swift, M. J., Heal, O. W. and Anderson, J. M. (1979). Decomposition in terrestrial ecosystems. Oakland, California: University of California Press.

Welke, S. E. and Parkinson, D. (2003). Effect of Aporrectodea trapezoides activity on seedling growth of Pseudotsuga menziesii, nutrient dynamics and microbial activity in different forest soils. Forest Ecology and Management, 173, p.169-186.

Wolters, V. and Stickan, W. (1991). Resource allocation of beech seedlings (Fagus sylvatica L.)-relationship to earthworm activity and soil conditions. Oecologia, 88 (1), p.125-131. 
Table 1. Viridor 0-25 mm PAS 100 Composted Green Waste summary nutrient analysis (source: technical document supplied by Viridor).

\begin{tabular}{lrrr}
\hline Parameter & $\begin{array}{r}\text { \% Dry } \\
\text { Mass }\end{array}$ & $\begin{array}{r}\mathrm{Kg} \mathrm{t}^{-1} \text { Fresh } \\
\text { Weight }\end{array}$ & $\begin{array}{r}\text { \% nutrient availability } \\
\text { (in first year) }\end{array}$ \\
\hline Nitrogen & 1.27 & 6.20 & 10 \\
Phosphate & 0.19 & 0.93 & 75 \\
Potash & 0.79 & 3.86 & 90 \\
Magnesium & 0.26 & 1.27 & 60 \\
Sulphur & 0.25 & 1.22 & 30 \\
Organic Matter & 60.20 & 293.78 & $\mathrm{n} / \mathrm{a}$ \\
\hline
\end{tabular}


Table 2. Selected soil parameters of Ingrebourne Hill, five years after restoration (data from Doick and Willoughby, 2011).

\begin{tabular}{lr}
\hline Parameter (unit) & Value \\
\hline Extractable-N $\left(\mathrm{mg} \mathrm{l}^{-1}\right)$ & 0.19 \\
$\mathrm{pH}$ & 7.9 \\
$\mathrm{C}: \mathrm{N}$ & 29 \\
Organic Matter (\%) & 4.0 \\
\hline
\end{tabular}


Table 3. Mean ( \pm SE) earthworm density, expressed in in No. mesocosm ${ }^{-1}$ (and equivalent $\mathrm{m}^{-2}$ ), after 12 months in PVC tubes containing experimental tree species and soil treatments. Different letters in a row indicate significant differences, ANOVA followed by Tukey-Kramer post-hoc test, $n=5, * p$ $<0.05$

\begin{tabular}{|c|c|c|c|c|c|}
\hline \multirow{2}{*}{$\begin{array}{l}\text { Earthworm } \\
\text { species }\end{array}$} & \multirow{2}{*}{$\begin{array}{l}\text { Baseline } \\
\text { density }\end{array}$} & \multicolumn{2}{|c|}{ A. cordata } & \multicolumn{2}{|c|}{ A. platanoides } \\
\hline & & $\begin{array}{l}\text { Earthworm } \\
\text { only (in) }\end{array}$ & $\begin{array}{l}\text { Earthworm } \\
\text { and CGW }\end{array}$ & $\begin{array}{l}\text { Earthworm } \\
\text { only }\end{array}$ & $\begin{array}{l}\text { Earthworm and } \\
\text { CGW }\end{array}$ \\
\hline A. longa & $5(100)$ & $\begin{array}{l}4.6 \pm 0.25^{a} \\
(92 \pm 5)\end{array}$ & $\begin{array}{l}3.8 \pm 0.59^{a} \\
(76 \pm 11.8)\end{array}$ & $\begin{array}{l}3.4 \pm 0.51^{a} \\
(68 \pm 10.2)\end{array}$ & $\begin{array}{l}3.2 \pm 0.59^{a} \\
(64 \pm 11.8)\end{array}$ \\
\hline A. chlorotica & $10(200)$ & $\begin{array}{l}2.2 \pm 0.73^{a} \\
(44 \pm 14.6)\end{array}$ & $\begin{array}{l}2.2 \pm 0.66^{a} \\
(44 \pm 13.2)\end{array}$ & $\begin{array}{l}1.8 \pm 0.37^{a} \\
(36 \pm 7.4)\end{array}$ & $\begin{array}{l}5.0 \pm 0.63^{b^{*}} \\
(100 \pm 12.6)\end{array}$ \\
\hline
\end{tabular}


Table 4. Mean $( \pm \mathrm{SE})$ baseline $(\mathrm{t}=0)$ chemical parameters of control soil and compost-amended soil.

Different letters in a row indicate significant differences, ANOVA followed by Tukey-Kramer post-hoc test, $\mathrm{n}=5, * \mathrm{p}<0.05^{* *}, \mathrm{p}<0.01, * * * \mathrm{p}<0.001$.

\begin{tabular}{|c|c|c|}
\hline \multirow[b]{2}{*}{ Chemical parameter } & \multicolumn{2}{|c|}{ Treatment } \\
\hline & Control soil & CGW-amended soil \\
\hline $\mathrm{pH}$ & $7.93 \pm 0.02 a$ & $8.02 \pm 0.03 b^{*}$ \\
\hline Cond. $(\mu \mathrm{s} / \mathrm{cm})$ & $3043 \pm 8$ & $2814 \pm 127$ \\
\hline Total N (\%) & $0.11 \pm 0.00 a$ & $0.14 \pm 0.00 b^{* * *}$ \\
\hline C (Org) (\%) & $2.00 \pm 0.04 a$ & $2.36 \pm 0.05 b^{* * *}$ \\
\hline O.M. (\%) & $3.44 \pm 0.07 a$ & $4.07 \pm 0.08 b^{* * *}$ \\
\hline $\mathrm{C}: \mathrm{N}$ ratio & $28.04 \pm 0.38 a$ & $24.44 \pm 0.36 b^{* * *}$ \\
\hline Moisture content (\%) & $20.58 \pm 1.00$ & $31.10 \pm 0.60$ \\
\hline $\mathrm{K}(\mathrm{mg} / \mathrm{kg})$ & $4029 \pm 151$ & $3876 \pm 21$ \\
\hline $\mathrm{Ca}(\mathrm{mg} / \mathrm{kg})$ & $33593 \pm 743 a$ & $30802 \pm 718 b^{*}$ \\
\hline $\mathrm{Mg}(\mathrm{mg} / \mathrm{kg})$ & $3652 \pm 61$ & $3647 \pm 121$ \\
\hline $\mathrm{Na}(\mathrm{mg} / \mathrm{kg})$ & $318 \pm 13.40$ & $323.90 \pm 11.20$ \\
\hline$P(\mathrm{mg} / \mathrm{kg})$ & $705 \pm 64.29$ & $729.78 \pm 13.40$ \\
\hline $\mathrm{S}(\mathrm{mg} / \mathrm{kg})$ & $1717 \pm 57 a$ & $1203 \pm 121 b^{* *}$ \\
\hline$\left[\mathrm{N}\left(\mathrm{NH}_{4}^{+}\right)\right](\mathrm{mg} / \mathrm{kg})$ & $2.75 \pm 0.29$ & $2.92 \pm 0.17$ \\
\hline$\left[\mathrm{N}\left(\mathrm{NO}_{3}{ }^{-}\right)\right](\mathrm{mg} / \mathrm{kg})$ & $11.46 \pm 0.09$ & $2.307 \pm 1.24 b^{* * *}$ \\
\hline $\mathrm{S}\left(\mathrm{SO}_{4}{ }^{2-}\right)(\mathrm{mg} / \mathrm{kg})$ & $1310 \pm 54 a$ & $584 \pm 77 b^{* * *}$ \\
\hline $\mathrm{P}\left(\mathrm{PO}_{4}{ }^{3-}\right)(\mathrm{mg} / \mathrm{kg})$ & $29.51 \pm 0.31 a$ & $39.38 \pm 0.65 b^{* * *}$ \\
\hline
\end{tabular}


Table 5. Effects of tree species on mean $( \pm \mathrm{SE})$ bulk soil chemical parameters after 12 months.

Different letters in a row indicate significant differences, ANOVA followed by Tukey-Kramer post-hoc test, $\mathrm{n}=5, * \mathrm{p}<0.05 * *, \mathrm{p}<0.01, * * * \mathrm{p}<0.001$.

\begin{tabular}{lrrr}
\hline & & & \multicolumn{2}{c}{ Tree species } \\
\cline { 3 - 4 } Chemical parameter & & \multicolumn{1}{c}{ A. platanoides } & A. cordata \\
\hline $\mathrm{pH}$ & $9.08 \pm 0.44$ & $8.90 \pm 0.08$ & $8.78 \pm 0.34$ \\
Cond. $(\mathrm{\mu s} / \mathrm{cm})$ & $828 \pm 100$ & $1187 \pm 171$ & $1697 \pm 335$ \\
Total $\mathrm{N}(\%)$ & $0.08 \pm 0.00$ & $0.08 \pm 0.00$ & $0.08 \pm 0.00$ \\
$\mathrm{C}(\mathrm{Org})(\%)$ & $1.72 \pm 0.03 \mathrm{a}$ & $1.79 \pm 0.04 \mathrm{a}$ & $1.86 \pm 0.05 \mathrm{~b}^{*}$ \\
$\mathrm{O} . \mathrm{M} .(\%)$ & $2.97 \pm 0.06 \mathrm{a}$ & $3.08 \pm 0.06 \mathrm{a}$ & $3.21 \pm 0.08 \mathrm{~b}^{*}$ \\
$\mathrm{C}: \mathrm{N} \mathrm{ratio}$ & $22.88 \pm 1.04$ & $23.19 \pm 1.13$ & $23.73 \pm 1.02$ \\
$\mathrm{Moisture} \mathrm{content}(\%)$ & $27.14 \pm 0.84 \mathrm{a}$ & $22.55 \pm 1.46 \mathrm{~b}^{* * *}$ & $17.01 \pm 1.18 \mathrm{c}^{* * *}$ \\
$\mathrm{~K}(\mathrm{mg} / \mathrm{kg})$ & $123.93 \pm 2.66 \mathrm{a}$ & $111.05 \pm 4.36 \mathrm{a}$ & $87.85 \pm 4.08 \mathrm{~b}^{* * *}$ \\
$\mathrm{Ca}(\mathrm{mg} / \mathrm{kg})$ & $2881 \pm 314$ & $2940 \pm 204$ & $3059 \pm 215$ \\
$\mathrm{Mg}(\mathrm{mg} / \mathrm{kg})$ & $66.38 \pm 4.97 \mathrm{a}$ & $66.66 \pm 5.27 \mathrm{a}$ & $59.23 \pm 4.46 \mathrm{~b}^{*}$ \\
$\mathrm{Na}(\mathrm{mg} / \mathrm{kg})$ & $14.85 \pm 0.49$ & $15.34 \pm 0.83$ & $16.21 \pm 0.73$ \\
{$\left[\mathrm{~N}\left(\mathrm{NH}{ }_{4}{ }^{+}\right)\right](\mathrm{mg} / \mathrm{kg})$} & $1.06 \pm 0.05$ & $1.03 \pm 0.08$ & $0.70 \pm 0.12$ \\
{$\left[\mathrm{~N}\left(\mathrm{NO}_{2}\right)\right](\mathrm{mg} / \mathrm{kg})$} & $0.36 \pm 0.22$ & $0.57 \pm 0.35$ & $0.26 \pm 0.15$ \\
{$\left[\mathrm{~N}\left(\mathrm{NO}_{3}{ }^{-}\right)\right](\mathrm{mg} / \mathrm{kg})$} & $0.52 \pm 0.06 \mathrm{a}$ & $0.41 \pm 0.03 \mathrm{a}$ & $0.18 \pm 0.02 \mathrm{~b}^{* * *}$ \\
$\mathrm{~S}\left(\mathrm{SO}_{4}{ }^{2-}\right)(\mathrm{mg} / \mathrm{kg})$ & $87.49 \pm 13.53$ & $209.08 \pm 57.97$ & $287.06 \pm 79.67$ \\
$\mathrm{P}\left(\mathrm{PO}_{4}{ }^{3-}\right)(\mathrm{mg} / \mathrm{kg})$ & $20.38 \pm 0.59 \mathrm{a}$ & $21.11 \pm 0.34 \mathrm{a}$ & $17.36 \pm 1.04 \mathrm{~b}^{* * *}$ \\
\hline
\end{tabular}




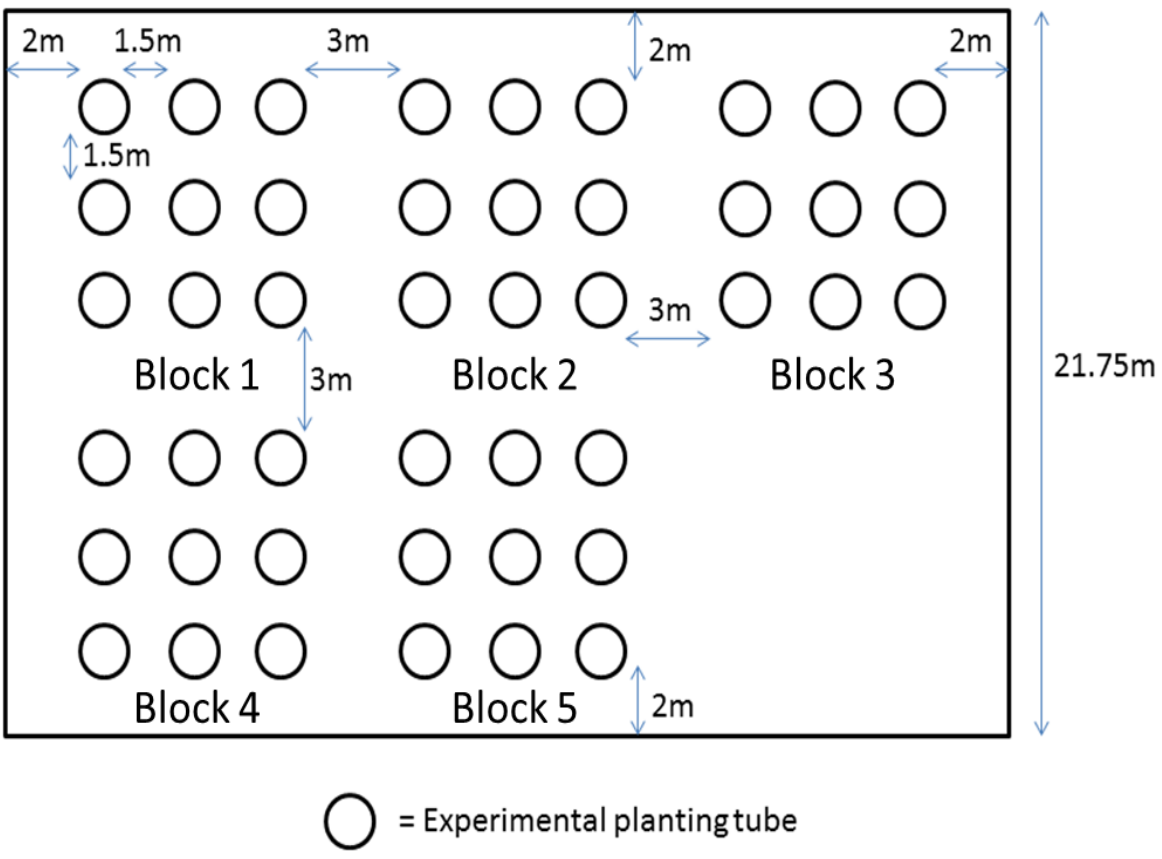

Figure 1. Experimental layout of planting tubes at Headley Nursery. 


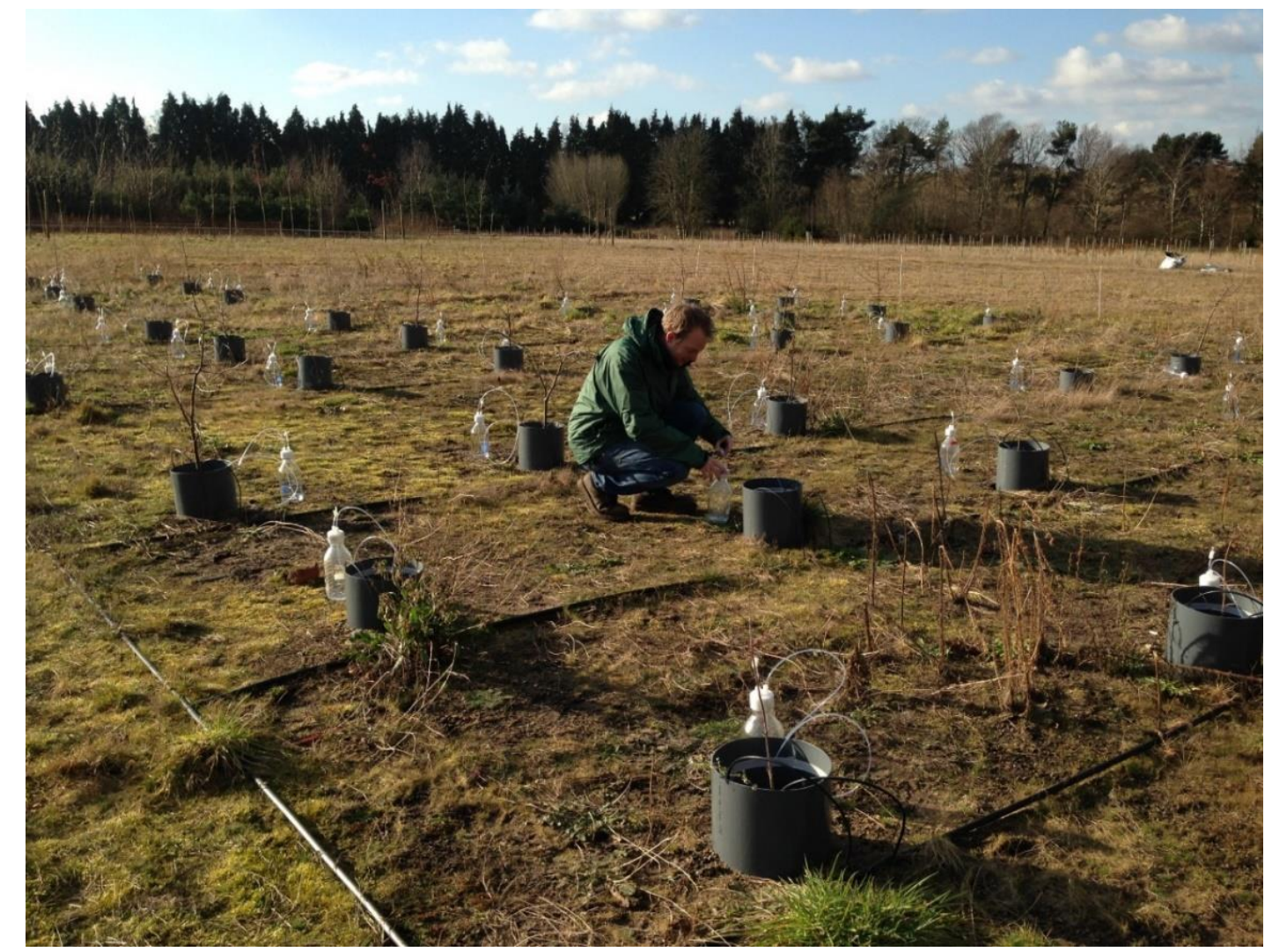

Figure 2. Inspection of mesocosms. In the foreground the drip-irrigation system is visible, as are the white velcro strips within the experimental tubes to prevent earthworm escape. 


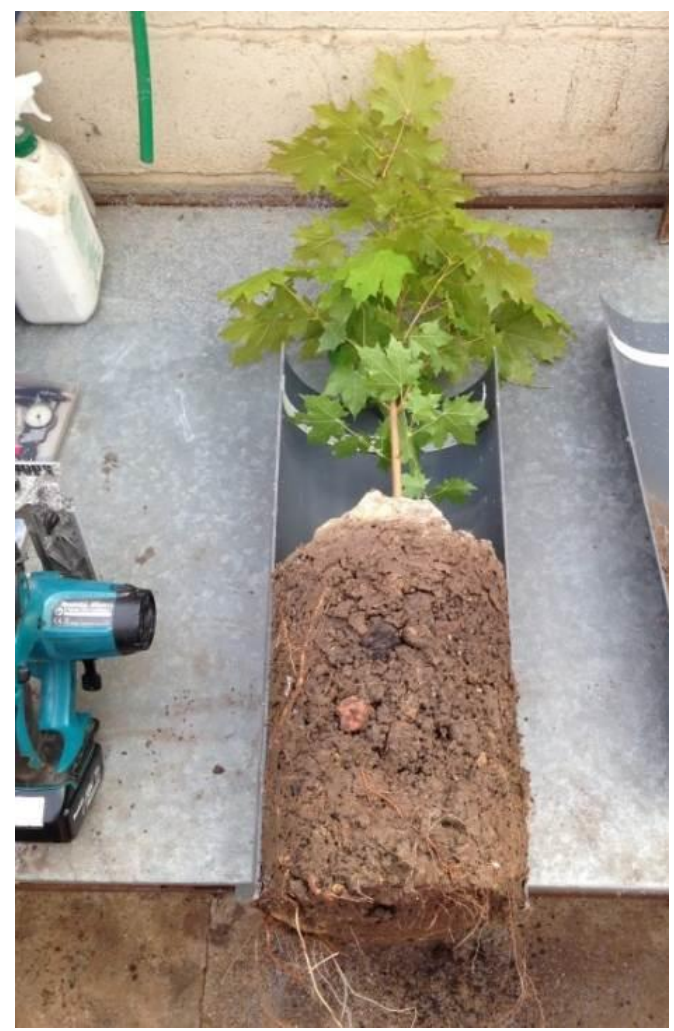

Figure 3. Destructive sampling of soil columns at termination of the experiment. A Norway maple (Acer platanoides) tube, cut with a circular saw to reveal the soil column and tree root system. 


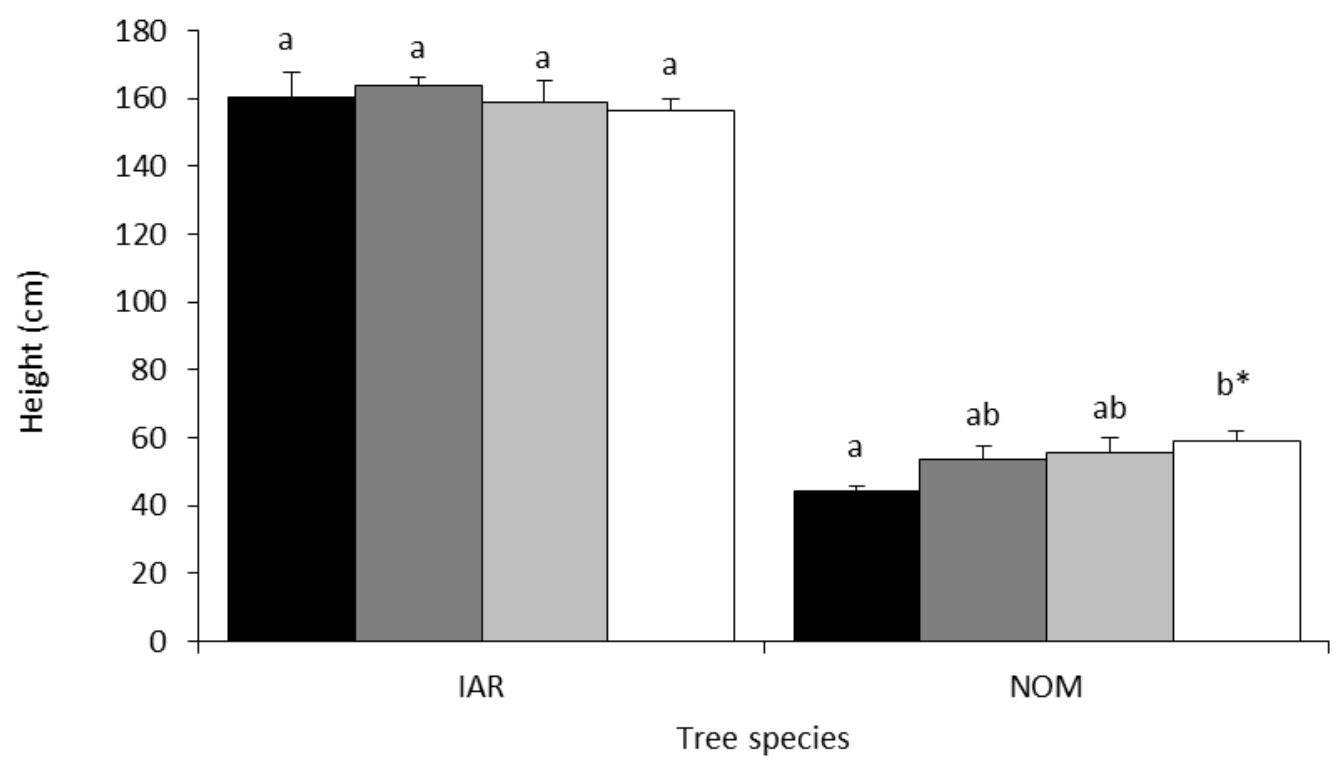

Figure 4. Mean $( \pm \mathrm{SE})$ height $(\mathrm{cm})$ of Alnus cordata (IAR) and Acer platanoides (NOM) after 12 months under experimental treatments: Control ( $\square$ ), Earthworm only ( $\square$ ), composted green waste (CGW) only $(\square)$, CGW plus earthworm ( $\square$ ). Different letters in a row indicate significant differences, ANOVA followed by Tukey-Kramer post-hoc test, $n=5, * p<0.05$. 


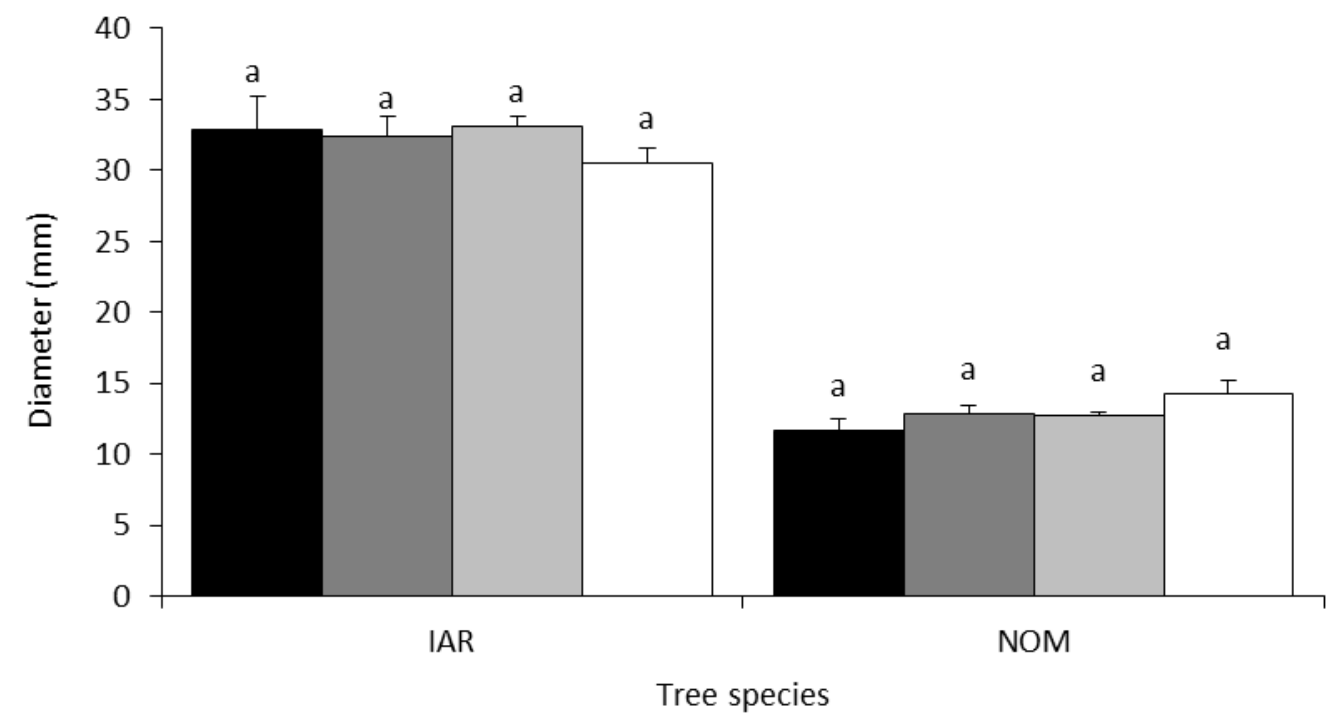

Figure 5. Mean ( $\pm \mathrm{SE}$ ) diameter $(\mathrm{mm})$ of Alnus cordata (IAR) and Acer platanoides (NOM) after 12 months under experimental treatments: Control $(\square)$, Earthworm only $(\square)$, composted green waste (CGW) only $(\square)$, CGW plus earthworm ( $\square$ ). Different letters in a row indicate significant differences, ANOVA followed by Tukey-Kramer post-hoc test, $\mathrm{n}=5$. 


\section{Supplementary material}

2 Table I. Mean $( \pm \mathrm{SE}$ ) effects of experimental treatments on soil chemical parameters after 12 months in mesocosm tubes containing Alnus cordata ( $\mathrm{n}=5$ ). Different letters in a row indicate significant differences, ANOVA followed by Tukey-Kramer post-hoc test, $n=5 * p<0.05 * *, p<0.01 * * * p<0.001$

4

\begin{tabular}{|c|c|c|c|c|c|c|}
\hline Soil Type & Chemical parameter & No tree & $\begin{array}{l}\text { A. cordata } \\
\text { Control }\end{array}$ & Earthworm only & CGW only & Earthworm and CGW \\
\hline \multirow{15}{*}{$0-0.2 \mathrm{~m}$ bulk Soil } & $\mathrm{pH}$ & & & & & \\
\hline & $\begin{array}{l}\mathrm{pH} \\
\text { Cond. }(\mu \mathrm{s} / \mathrm{cm})\end{array}$ & $\begin{array}{l}8.52 \pm 0.04 \\
1356.98 \pm 293.85\end{array}$ & $\begin{array}{l}8.70 \pm 0.08 \\
1008.68 \pm 101.58\end{array}$ & $\begin{array}{l}8.66 \pm 0.08 \\
1098.1 \pm 112.15\end{array}$ & $\begin{array}{l}8.48 \pm 0.09 \\
1143.1 \pm 242.04\end{array}$ & $\begin{array}{l}8.50 \pm 0.03 \\
867.6 \pm 50.83\end{array}$ \\
\hline & Total N (\%) & $0.08 \pm 0.00 \mathrm{a}$ & $0.08 \pm 0.00 \mathrm{a}$ & $0.08 \pm 0.00 \mathrm{ab}$ & $0.10 \pm 0.00 b^{* * *}$ & $0.10 \pm 0.00 \mathrm{~b}^{* * *}$ \\
\hline & $\mathrm{C}(\mathrm{Org})(\%)$ & $1.72 \pm 0.03 a$ & $1.79 \pm 0.07 \mathrm{ab}$ & $1.94 \pm 0.13 \mathrm{ab}$ & $2.03 \pm 0.04 \mathrm{ab}$ & $2.07 \pm 0.10 \mathrm{~b}^{*}$ \\
\hline & O.M. (\%) & $2.96 \pm 0.05 a$ & $3.08 \pm 0.12 \mathrm{ab}$ & $3.35 \pm 0.22 \mathrm{ab}$ & $3.50 \pm 0.07 a b$ & $3.56 \pm 0.17 \mathrm{~b}^{*}$ \\
\hline & C:N ratio & $22.54 \pm 0.53 \mathrm{ab}$ & $23.01 \pm 0.8 \mathrm{ab}$ & $23.25 \pm 0.78 \mathrm{~b}^{*}$ & $20.59 \pm 0.24 a$ & $21.30 \pm 0.27 \mathrm{ab}$ \\
\hline & moisture content (\%) & $23.14 \pm 0.53 b^{\star \star *}$ & $16.65 \pm 0.98 \mathrm{a}$ & $16.63 \pm 1.34 a$ & $14.93 \pm 0.69 a$ & $16.56 \pm 0.450 \mathrm{a}$ \\
\hline & $\mathrm{K}(\mathrm{mg} / \mathrm{kg})$ & $132.27 \pm 3.11 \mathrm{~b}^{* *}$ & $100.78 \pm 6.14 a$ & $96.97 \pm 3.54 a$ & $115.21 \pm 3.98 \mathrm{ab}$ & $113.09 \pm 8.74 a b$ \\
\hline & $\mathrm{Ca}(\mathrm{mg} / \mathrm{kg})$ & $2691.05 \pm 113.35$ & $2787.3 \pm 58.04$ & $2815.46 \pm 82.78$ & $2963.35 \pm 76.94$ & $2661.3 \pm 43.17$ \\
\hline & $\mathrm{Mg}(\mathrm{mg} / \mathrm{kg})$ & $72.36 \pm 5.74$ & $61.45 \pm 3.94$ & $61.77 \pm 5.30$ & $75.97 \pm 4.09$ & $73.68 \pm 4.17$ \\
\hline & $\mathrm{Na}(\mathrm{mg} / \mathrm{kg})$ & $14.86 \pm 0.63$ & $14.65 \pm 0.38$ & $16.62 \pm 0.69$ & $16.73 \pm 0.58$ & $15.01 \pm 0.54$ \\
\hline & {$\left[\mathrm{N}\left(\mathrm{NH}_{4}^{+}\right)\right](\mathrm{mg} / \mathrm{kg})$} & $1.13 \pm 0.06 \mathrm{ab}$ & $1.20 \pm 0.10 \mathrm{~b}$ & $0.65 \pm 0.19 a$ & $1.31 \pm 0.06 \mathrm{~b}^{*}$ & $1.00 \pm 0.153 \mathrm{ab}$ \\
\hline & {$\left[\mathrm{N}\left(\mathrm{NO}_{2}-\right]\right](\mathrm{mg} / \mathrm{kg})$} & $0.52 \pm 0.33$ & $0.29 \pm 0.17$ & $0.10 \pm 0.04$ & $0.12 \pm 0.02$ & $0.09 \pm 0.03$ \\
\hline & {$\left[\mathrm{N}^{\left.\mathrm{N}\left(\mathrm{NO}_{3}\right)\right]}\right](\mathrm{mg} / \mathrm{kg})$} & $0.45 \pm 0.06$ & $0.29 \pm 0.08$ & $\begin{array}{l}0.21 \pm 0.06 \\
15958+258\end{array}$ & $0.32 \pm 0.04$ & $0.27 \pm 0.08$ \\
\hline & 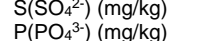 & $\begin{array}{l}190.33 \pm 45.29 \\
21.82 \pm 1.04 b^{* * *}\end{array}$ & $\begin{array}{l}124.19 \pm 14.95 \\
18.69 \pm 0.7 a\end{array}$ & $\begin{array}{l}159.58 \pm 25.8 \\
18.65 \pm 0.37 a\end{array}$ & $\begin{array}{l}202.1 \pm 90.15 \\
22.12 \pm 0.53 b^{\star \star *}\end{array}$ & $\begin{array}{l}86.17 \pm 9.46 \\
23.48 \pm 0.63 b^{* * *}\end{array}$ \\
\hline \multirow{15}{*}{$0-0.2 \mathrm{~m}$ rhizosphere soil } & & $\mathrm{N} / \mathrm{A}$ & $8.48 \pm 0.11$ & $8.62 \pm 0.08$ & $8.40 \pm 0.09$ & $8.58 \pm 0.07$ \\
\hline & Cond. $(\mu \mathrm{s} / \mathrm{cm})$ & $N / A$ & $1039.5 \pm 146.65$ & $1073.0 \pm 146.68$ & $752.1 \pm 32.41$ & $881.0 \pm 13.68$ \\
\hline & Total N (\%) & $N / A$ & $0.12 \pm 0.01$ & $0.10 \pm 0.01$ & $0.12 \pm 0.01$ & $0.12 \pm 0.01$ \\
\hline & $\mathrm{C}(\mathrm{Org})(\%)$ & $\mathrm{N} / \mathrm{A}$ & $2.72 \pm 0.24$ & $2.25 \pm 0.10$ & $2.42 \pm 0.11$ & $2.58 \pm 0.14$ \\
\hline & O.M. (\%) & $\mathrm{N} / \mathrm{A}$ & $4.68 \pm 0.41$ & $3.89 \pm 0.17$ & $4.16 \pm 0.19$ & $4.46 \pm 0.24$ \\
\hline & C:N ratio & $\mathrm{N} / \mathrm{A}$ & $23.13 \pm 0.48 \mathrm{~b}$ & $22.5 \pm 0.44 b$ & $19.83 \pm 0.44 \mathrm{a}^{\star \star \star}$ & $21.91 \pm 0.61 b$ \\
\hline & moisture content (\%) & $\mathrm{N} / \mathrm{A}$ & $22.65 \pm 1.62$ & $18.20 \pm 1.89$ & $17.18 \pm 1.26$ & $19.19 \pm 1.17$ \\
\hline & $\mathrm{K}(\mathrm{mg} / \mathrm{kg})$ & $\mathrm{N} / \mathrm{A}$ & $91.09 \pm 3.9$ & $92.73 \pm 3.76$ & $96.9 \pm 6.77$ & $100.75 \pm 2.75$ \\
\hline & $\mathrm{Ca}(\mathrm{mg} / \mathrm{kg})$ & $\mathrm{N} / \mathrm{A}$ & $3159.25 \pm 171.27$ & $2934.24 \pm 131.38$ & $2994.6 \pm 154.01$ & $3120.36 \pm 56.64$ \\
\hline & $\mathrm{Mg}(\mathrm{mg} / \mathrm{kg})$ & N/A & $101.73 \pm 6.93$ & $91.97 \pm 5.96$ & $99.52 \pm 6.15$ & $103.16 \pm 7.66$ \\
\hline & $\mathrm{Na}(\mathrm{mg} / \mathrm{kg})$ & N/A & $21.97 \pm 0.96$ & $21.68 \pm 1.09$ & $21.79 \pm 1.61$ & $21.12 \pm 1.46$ \\
\hline & {$\left[\mathrm{N}\left(\mathrm{NH}_{4}+\right)\right](\mathrm{mg} / \mathrm{kg})$} & N/A & $2.12 \pm 0.28 \mathrm{~b}^{*}$ & $1.04 \pm 0.14 a$ & $1.90 \pm 0.35 \mathrm{ab}$ & $1.22 \pm 0.31 \mathrm{ab}$ \\
\hline & {$\left[\mathrm{N}\left(\mathrm{NO}_{2}\right)\right](\mathrm{mg} / \mathrm{kg})$} & $\begin{array}{ll}N / A \\
N / A\end{array}$ & $0.08 \pm 0.01$ & $0.09 \pm 0.01$ & $0.10 \pm 0.02$ & \\
\hline & 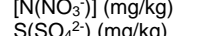 & $\begin{array}{l}N / A \\
N / A\end{array}$ & $\begin{array}{l}0.23 \pm 0.05 \\
7784+23.5\end{array}$ & $0.14 \pm 0.01$ & $0.23 \pm 0.06$ & $0.22 \pm 0.05$ \\
\hline & 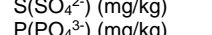 & $\begin{array}{l}N / A \\
N / A\end{array}$ & $\begin{array}{l}77.84 \pm 23.5 \\
1948+118 \mathrm{ab}\end{array}$ & $\begin{array}{l}85.95 \pm 21.65 \\
1865+0.56 a\end{array}$ & $\begin{array}{l}47.54 \pm 8.10 \\
2311+1.48 \mathrm{~b}^{*}\end{array}$ & $\begin{array}{l}50.76 \pm 10.29 \\
22.5\end{array}$ \\
\hline \multirow[t]{15}{*}{$0.2-0.4 \mathrm{~m}$ bulk soil } & $\mathrm{pH}$ & $\begin{array}{l}N / A \\
9.08 \pm 0.44\end{array}$ & $\begin{array}{l}19.48 \pm 1.18 \mathrm{ab} \\
8.78 \pm 0.34\end{array}$ & $\begin{array}{l}8.65 \pm 0.07 \mathrm{a} \\
8.62 \pm 0.07\end{array}$ & $\begin{array}{l}23.44 \pm 0.09 \\
8.440\end{array}$ & $\begin{array}{l}8.62 \pm 0.07 \\
8.52 a 0\end{array}$ \\
\hline & Cond. $(\mu \mathrm{s} / \mathrm{cm})$ & $827.80 \pm 100.41 \mathrm{a}$ & $1691.6 \pm 334.68 \mathrm{~b}^{*}$ & $936.3 \pm 127.12 \mathrm{ab}$ & $877.7 \pm 148.49 a$ & $841.1 \pm 71.56 \mathrm{a}$ \\
\hline & Total N (\%) & $0.08 \pm 0.00 \mathrm{a}$ & $0.08 \pm 0.00 \mathrm{a}$ & $0.08 \pm 0.00 \mathrm{a}$ & $0.12 \pm 0.00 b^{* \star *}$ & $0.1 \pm 0.00 \mathrm{c}^{\star \star \star}$ \\
\hline & $\mathrm{C}(\mathrm{Org})(\%)$ & $1.72 \pm 0.04 a$ & $1.86 \pm 0.05 a$ & $1.83 \pm 0.06 a$ & $2.23 \pm 0.04 b^{\star \star \star}$ & $2.16 \pm 0.07 b^{\star \star *}$ \\
\hline & О.М. (\%) & $2.97 \pm 0.06 a$ & $3.21 \pm 0.08 a$ & $3.15 \pm 0.10 \mathrm{a}$ & $3.84 \pm 0.07 b^{\star \star \star}$ & $3.72 \pm 0.12 b^{\star \star \star}$ \\
\hline & C:N ratio & $22.88 \pm 1.04 \mathrm{~b}^{\star *}$ & $23.73 \pm 1.02 b^{* *}$ & $22.54 \pm 0.52 b^{* *}$ & $19.31 \pm 0.30 \mathrm{a}$ & $21.71 \pm 0.51 \mathrm{ab}$ \\
\hline & moisture content (\%) & $27.14 \pm 0.84 \mathrm{~b}^{\star * \star}$ & $17.01 \pm 1.18 \mathrm{a}$ & $18.19 \pm 1.68 \mathrm{a}$ & $16.06 \pm 1.01 \mathrm{a}$ & $17.97 \pm 0.96 a$ \\
\hline & $\mathrm{K}(\mathrm{mg} / \mathrm{kg})$ & $123.93 \pm 2.66 \mathrm{~b}^{* * *}$ & $87.85 \pm 4.08 \mathrm{a}$ & $83.06 \pm 2.89 a$ & $96.89 \pm 5.82 a$ & $99.49 \pm 5.13 a$ \\
\hline & $\mathrm{Ca}(\mathrm{mg} / \mathrm{kg})$ & $2880.70 \pm 313.66$ & $3059.31 \pm 214.48$ & $2710.74 \pm 75.05$ & $2867.89 \pm 106.31$ & $2917.29 \pm 56.77$ \\
\hline & $\mathrm{Mg}(\mathrm{mg} / \mathrm{kg})$ & $66.38 \pm 4.97$ & $59.23 \pm 4.46$ & $66.01 \pm 3.81$ & $71.74 \pm 5.41$ & $71.66 \pm 4.40$ \\
\hline & $\mathrm{Na}(\mathrm{mg} / \mathrm{kg})$ & $14.85 \pm 0.49$ & $16.21 \pm 0.73$ & $18.11 \pm 0.58$ & $17.78 \pm 1.35$ & $17.44 \pm 0.91$ \\
\hline & {$\left[\mathrm{N}\left(\mathrm{NH}_{4}+\right)\right](\mathrm{mg} / \mathrm{kg})$} & $1.06 \pm 0.05$ & $0.70 \pm 0.12$ & $0.40 \pm 0.18$ & $0.91 \pm 0.20$ & $0.90 \pm 0.23$ \\
\hline & {$\left[\mathrm{N}\left(\mathrm{NO}_{2}{ }^{-}\right)\right](\mathrm{mg} / \mathrm{kg})$} & $0.36 \pm 0.23$ & $0.26 \pm 0.15$ & $0.05 \pm 0.02$ & $0.11 \pm 0.01$ & $0.14 \pm 0.05$ \\
\hline & {$\left[\mathrm{N}\left(\mathrm{NO}_{3}{ }^{-}\right)\right](\mathrm{mg} / \mathrm{kg})$} & $0.53 \pm 0.06 \mathrm{~b}^{\star \star \star}$ & $0.18 \pm 0.02 a$ & $0.16 \pm 0.05 a$ & $0.22 \pm 0.06 a$ & $0.29 \pm 0.06 a$ \\
\hline & $\mathrm{S}\left(\mathrm{SO}_{4}{ }^{2}\right)(\mathrm{mg} / \mathrm{kg})$ & $87.49 \pm 13.53 a$ & $287.07 \pm 79.67 \mathrm{~b}^{*}$ & $151.68 \pm 54.98 \mathrm{ab}$ & $91.02 \pm 16.81 \mathrm{a}$ & $95.88 \pm 15.39 a$ \\
\hline
\end{tabular}


5 Table II. Mean ( \pm SE) effects of experimental treatments on soil chemical parameters after 12 months in mesocosm tubes containing Acer platanoides $(\mathrm{n}=5)$. Different letters in a row indicate significant differences, ANOVA followed by Tukey-Kramer post-hoc test, $n=5,{ }^{*} p<0.05 * *, p<0.01,{ }^{* * *} p<0.001$.

7

\begin{tabular}{|c|c|c|c|c|c|c|}
\hline \multirow[b]{2}{*}{ Soil Type } & \multirow[b]{2}{*}{ Chemical parameter } & \multirow[b]{2}{*}{ No tree } & \multicolumn{4}{|l|}{ A. platanoides } \\
\hline & & & Control & Earthworm only & CGW only & Earthworm and CGW \\
\hline \multirow{16}{*}{0 - $0.2 \mathrm{~m}$ Bulk Soil } & $\mathrm{pH}$ & $8.52 \pm 0.04$ & $872+005$ & $860+013$ & $802+011$ & $870+010$ \\
\hline & Cond. $(\mu \mathrm{s} / \mathrm{cm})$ & $1356.98 \pm 293.85 a$ & $761.6 \pm 62.52 \mathrm{ab}$ & $9497+7548 a b$ & $7579+55754 a b$ & $\begin{array}{l}8.72 \pm 0.10 \\
6846+98.89 b^{*}\end{array}$ \\
\hline & Total N (\%) & $0.08 \pm 0.00 \mathrm{a}$ & $0.08 \pm 0.00 \mathrm{a}$ & $0.08 \pm 0.00 \mathrm{a}$ & $0.1 \pm 0.00 \mathrm{~b}^{* \star \star}$ & $0.09+0.00 b^{* * *}$ \\
\hline & $\mathrm{C}(\mathrm{Org})(\%)$ & $1.72 \pm 0.03 a$ & $1.69 \pm 0.02 a$ & $1.75 \pm 0.05 a$ & $2.09 \pm 0.05 \mathrm{c}^{\star \star \star}$ & $1.93 \pm 0.02 b^{* \star *}$ \\
\hline & O.M. (\%) & $2.96 \pm 0.05 \mathrm{a}$ & $2.91 \pm 0.03 \mathrm{a}$ & $3.02 \pm 0.08 \mathrm{a}$ & $3.6 \pm 0.09 b^{* \star *}$ & $3.33 \pm 0.03 \mathrm{c}^{\star \star \star}$ \\
\hline & $\begin{array}{l}\text { C:N ratio } \\
\text { moisture content (\%) }\end{array}$ & $\begin{array}{l}22.54 \pm 0.53 a b \\
23.14+0.58\end{array}$ & $\begin{array}{l}22.25 \pm 0.55 \mathrm{ab} \\
21.24+0.71\end{array}$ & $\begin{array}{l}23.38 \pm 0.50 \mathrm{~b}^{\star} \\
20.69+0.58\end{array}$ & $\begin{array}{l}20.85 \pm 0.66 a \\
19.36+1.78\end{array}$ & $20.87 \pm 0.78 \mathrm{a}$ \\
\hline & $\begin{array}{l}\text { moisture content (\%) } \\
\mathrm{K}(\mathrm{mg} / \mathrm{kg})\end{array}$ & $\begin{array}{l}22.14 \pm 0.58 \\
132.27 \pm 3.11 \mathrm{a}\end{array}$ & $\begin{array}{l}21.24 \pm 0 . / 7 \\
129.05 \pm 2.86 \mathrm{ab}\end{array}$ & $125.16 \pm 4.68 \mathrm{ab}$ & $150.65 \pm 8.05 \mathrm{~b}^{*}$ & $140.58 \pm 7.59 \mathrm{ab}$ \\
\hline & $\mathrm{Ca}(\mathrm{mg} / \mathrm{kg})$ & $2691.05 \pm 113.35$ & $2777.75 \pm 54.43$ & $2745.83 \pm 36.9$ & $2972.11 \pm 90.24$ & $2779.5 \pm 135.63$ \\
\hline & $\mathrm{Mg}(\mathrm{mg} / \mathrm{kg})$ & $72.36 \pm 5.74$ & $89.62 \pm 8.36$ & $75.82 \pm 6.53$ & $87.56 \pm 4.55$ & $88.95 \pm 4.88$ \\
\hline & $\mathrm{Na}(\mathrm{mg} / \mathrm{kg})$ & $14.86 \pm 0.63$ & $15.98 \pm 0.63$ & $15.93 \pm 0.67$ & $16.56 \pm 0.64$ & $15.36 \pm 0.64$ \\
\hline & {$\left[\mathrm{N}\left(\mathrm{NH}_{4}+\right)\right](\mathrm{mg} / \mathrm{kg})$} & $1.13 \pm 0.06 \mathrm{ab}$ & $1.31 \pm 0.07 \mathrm{ab}$ & $0.93 \pm 0.20 \mathrm{a}$ & $1.49 \pm 0.11 \mathrm{~b}^{*}$ & $1.41 \pm 0.08 \mathrm{ab}$ \\
\hline & $\left.\left[\mathrm{N}\left(\mathrm{NO}_{2}\right)\right]\right](\mathrm{mg} / \mathrm{kg})$ & $0.52 \pm 0.33$ & $0.14 \pm 0.03$ & $0.17 \pm 0.06$ & $0.12 \pm 0.05$ & $0.44 \pm 0.16$ \\
\hline & $\left.\left[\mathrm{N}\left(\mathrm{NO}_{3}\right)\right]\right](\mathrm{mg} / \mathrm{kg})$ & $0.45 \pm 0.06$ & $0.39 \pm 0.05$ & $0.35 \pm 0.10$ & $0.58 \pm 0.27$ & $0.56 \pm 0.09$ \\
\hline & $\mathrm{S}^{2}\left(\mathrm{SO}_{4}{ }^{2}\right)(\mathrm{mg} / \mathrm{kg})$ & $190.33 \pm 45.29$ & $103.47 \pm 12.68$ & $166.93 \pm 55.68$ & $79.8 \pm 19.58$ & $92.6 \pm 31.03$ \\
\hline & $\mathrm{P}\left(\mathrm{PO}_{4}^{3}\right)(\mathrm{mg} / \mathrm{kg})$ & $21.82 \pm 1.04 a$ & $21.41 \pm 1.01 \mathrm{a}$ & $21.14 \pm 0.51 \mathrm{a}$ & $26.86 \pm 1.58 b^{\star \star}$ & $25.87 \pm 1.42 a b$ \\
\hline & $\mathrm{pH}$ & $\mathrm{N} / \mathrm{A}$ & $8.46 \pm 0.09$ & $8.52 \pm 0.06$ & $8.32 \pm 0.09$ & $6.82 \pm 1.71$ \\
\hline \multirow[t]{14}{*}{0 - $0.2 \mathrm{~m}$ Rhizo soil } & Cond. $(\mu \mathrm{s} / \mathrm{cm})$ & N/A & $845.7 \pm 277.84$ & $565.3 \pm 409.5$ & $314.6 \pm 193.4$ & $446.9 \pm 195.37$ \\
\hline & Total N (\%) & N/A & $0.12 \pm 0.01$ & $0.11 \pm 0.01$ & $0.15 \pm 0.02$ & $0.10 \pm 0.03$ \\
\hline & $\mathrm{C}(\mathrm{Org})(\%)$ & $N / A$ & $3.35 \pm 0.42$ & $3.02 \pm 0.45$ & $4.22 \pm 0.68$ & $2.35 \pm 0.64$ \\
\hline & O.M. (\%) & N/A & $5.77 \pm 0.72$ & $5.21 \pm 0.78$ & $7.27 \pm 1.16$ & $4.05 \pm 1.11$ \\
\hline & C:N ratio & N/A & $27.74 \pm 1.73 a$ & $27.82 \pm 2.31 \mathrm{a}$ & $28.06 \pm 1.13 a$ & $17.97 \pm 4.54 \mathrm{~b}^{*}$ \\
\hline & moisture content (\%) & N/A & $34.36 \pm 2.73$ & $30.93 \pm 3.93$ & $29.58 \pm 3.30$ & $25.95 \pm 2.21$ \\
\hline & $\begin{array}{l}\mathrm{K}(\mathrm{mg} / \mathrm{kg}) \\
\mathrm{Ca}(\mathrm{mg} / \mathrm{kg})\end{array}$ & $\begin{array}{l}\text { N/A } \\
\text { N/A }\end{array}$ & $\begin{array}{l}114.34 \pm 4.32 \\
3465.21 \pm 280.22\end{array}$ & $\begin{array}{l}136.49 \pm 5.1 \\
3377.16 \pm 97.96\end{array}$ & $\begin{array}{l}131.43 \pm 8.78 \\
3656.88 \pm 284.05\end{array}$ & $\begin{array}{l}111.37 \pm 27.92 \\
2663.15 \pm 699.1\end{array}$ \\
\hline & $\mathrm{Mg}(\mathrm{mg} / \mathrm{kg})$ & $\mathrm{N} / \mathrm{A}$ & $148.54 \pm 14.86$ & $147.29 \pm 7.56$ & $\begin{array}{l}151.93 \pm 20.17 \\
151.00\end{array}$ & $115.13 \pm 31.56$ \\
\hline & $\mathrm{Na}(\mathrm{mg} / \mathrm{kg})$ & $\mathrm{N} / \mathrm{A}$ & $21.88 \pm 1.83$ & $23.96 \pm 2.11$ & $22.59 \pm 0.80$ & $17.64 \pm 4.68$ \\
\hline & {$\left[\mathrm{N}\left(\mathrm{NH}_{4}^{+}\right)\right](\mathrm{mg} / \mathrm{kg})$} & N/A & $2.30 \pm 0.44$ & $1.64 \pm 0.23$ & $3.01 \pm 0.53$ & $2.37 \pm 0.21$ \\
\hline & {$\left[\mathrm{N}\left(\mathrm{NO}_{2}\right)\right](\mathrm{mg} / \mathrm{kg})$} & $\mathrm{N} / \mathrm{A}$ & $0.08 \pm 0.01$ & $0.08 \pm 0.02$ & $0.09 \pm 0.01$ & $0.11 \pm 0.04$ \\
\hline & {$\left[\mathrm{N}\left(\mathrm{NO}_{3}\right)\right](\mathrm{mg} / \mathrm{kg})$} & $\mathrm{N} / \mathrm{A}$ & $0.38 \pm 0.08$ & $0.61 \pm 0.09$ & $0.43 \pm 0.20$ & $0.47 \pm 0.07$ \\
\hline & $\mathrm{S}\left(\mathrm{SO}_{4} 4^{2-}\right)(\mathrm{mg} / \mathrm{kg})$ & N/A & $99.81 \pm 47.15$ & $114.86 \pm 47.69$ & $36.33 \pm 5.05$ & $31.3 \pm 9.14$ \\
\hline & $\mathrm{P}\left(\mathrm{PO}_{4} 4^{-3}\right)(\mathrm{mg} / \mathrm{kg})$ & $\mathrm{N} / \mathrm{A}$ & $22.35 \pm 1.41$ & $26.13 \pm 1.81$ & $25.12 \pm 2.27$ & $23.3 \pm 5.93$ \\
\hline \multirow[t]{16}{*}{$0.2-0.4 \mathrm{~m}$ Bulk soil } & $\mathrm{pH}$ & $9.08 \pm 0.44$ & $8.9 \pm 0.08$ & $8.62 \pm 0.09$ & $8.68 \pm 0.14$ & $8.50 \pm 0.06$ \\
\hline & Cond. $(\mu \mathrm{s} / \mathrm{cm})$ & $827.8 \pm 100.41 \mathrm{ab}$ & $1186.5 \pm 171.09 b^{* *}$ & $757.6 \pm 86.12 \mathrm{a}$ & $694.8 \pm 17.1 \mathrm{a}$ & $595 \pm 33.41 \mathrm{a}$ \\
\hline & Total N (\%) & $0.08 \pm 0.00 \mathrm{a}$ & $0.08 \pm 0.00 \mathrm{a}$ & $0.08 \pm 0.00 \mathrm{a}$ & $0.10 \pm 0.01 b^{\star \star \star}$ & $0.11 \pm 0.00 \mathrm{~b}^{* \star *}$ \\
\hline & $\mathrm{C}(\mathrm{Org})(\%)$ & $1.72 \pm 0.04$ & $1.79 \pm 0.04$ & $1.81 \pm 0.05$ & $2.10 \pm 0.05$ & $2.16 \pm 0.07$ \\
\hline & O.M. (\%) & $2.97 \pm 0.06 \mathrm{a}$ & $3.08 \pm 0.06 \mathrm{a}$ & $3.13 \pm 0.09 a$ & $3.62 \pm 0.08 \mathrm{~b}^{\star \star *}$ & $3.73 \pm 0.12 b^{\star \star *}$ \\
\hline & C:N ratio & $22.88 \pm 1.04 \mathrm{ab}$ & $23.19 \pm 1.13 a b$ & $24.15 \pm 1.28 \mathrm{~b}^{\star \star}$ & $20.31 \pm 0.59 a b$ & $19.43 \pm 0.52 a$ \\
\hline & moisture content (\%) & $27.14 \pm 0.84 a$ & $22.55 \pm 1.46$ & $24.01 \pm 0.41$ & $21.02 \pm 2.01$ & $22.80 \pm 0.52$ \\
\hline & $\mathrm{K}(\mathrm{mg} / \mathrm{kg})$ & $123.93 \pm 2.66$ & $111.05 \pm 4.36$ & $117.62 \pm 5.93$ & $128.33 \pm 5.77$ & $125.26 \pm 4.60$ \\
\hline & $\mathrm{Ca}(\mathrm{mg} / \mathrm{kg})$ & $2880.7 \pm 313.66$ & $2939.5 \pm 203.53$ & $2643.66 \pm 107.06$ & $2958.92 \pm 194.68$ & $2718.28 \pm 83.27$ \\
\hline & $\mathrm{Mg}(\mathrm{mg} / \mathrm{kg})$ & $66.38 \pm 4.97 a$ & $66.66 \pm 5.27 a$ & $77.71 \pm 4.71 \mathrm{ab}$ & $78.06 \pm 6.38 \mathrm{ab}$ & $90.82 \pm 3.32 b^{*}$ \\
\hline & $\mathrm{Na}(\mathrm{mg} / \mathrm{kg})$ & $14.85 \pm 0.49$ & $15.34 \pm 0.83$ & $16.21 \pm 0.75$ & $17.08 \pm 1.20$ & $17.27 \pm 0.66$ \\
\hline & {$\left[\mathrm{N}\left(\mathrm{NH}_{4}{ }^{+}\right)\right](\mathrm{mg} / \mathrm{kg})$} & $1.06 \pm 0.05 a b$ & $1.03 \pm 0.08$ & $0.75 \pm 0.13$ & $1.43 \pm 0.16$ & $1.21 \pm 0.10$ \\
\hline & {$\left[\mathrm{N}\left(\mathrm{NO}_{2}{ }^{-}\right)\right](\mathrm{mg} / \mathrm{kg})$} & $0.36 \pm 0.23$ & $0.36 \pm 0.35$ & $0.58 \pm 0.08$ & $0.13 \pm 0.05$ & $0.15 \pm 0.04$ \\
\hline & {$\left[\mathrm{N}\left(\mathrm{NO}_{3}\right)\right](\mathrm{mg} / \mathrm{kg})$} & $0.53 \pm 0.06$ & $0.53 \pm 0.063$ & $0.78 \pm 0.35$ & $0.29 \pm 0.13$ & $0.37 \pm 0.30$ \\
\hline & $\mathrm{S}\left(\mathrm{SO}_{4}{ }^{2}\right)(\mathrm{mg} / \mathrm{kg})$ & $87.49 \pm 13.53 \mathrm{ab}$ & $209.08 \pm 57.97 b^{*}$ & $99.66 \pm 27.74 a b$ & $110.52 \pm 32.61 \mathrm{ab}$ & $48.42 \pm 8.02 a$ \\
\hline & $\mathrm{P}\left(\mathrm{PO}_{4}{ }^{3-}\right)(\mathrm{mg} / \mathrm{kg})$ & $20.38 \pm 0.59 \mathrm{a}$ & $21.11 \pm 0.34 a$ & $20.55 \pm 0.49 a$ & $24.64 \pm 1.86 \mathrm{~b}^{*}$ & $24.93 \pm 1.33 \mathrm{~b}^{*}$ \\
\hline
\end{tabular}




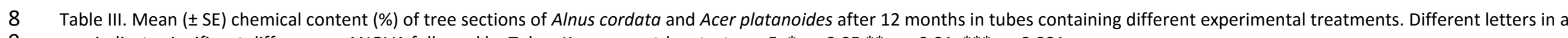
9 row indicate significant differences, ANOVA followed by Tukey-Kramer post-hoc test, $n=5, * p<0.05 * *, p<0.01,{ }^{* * *} p<0.001$.

\begin{tabular}{|c|c|c|c|c|c|c|c|c|c|}
\hline \multirow{2}{*}{$\begin{array}{l}\text { Tree } \\
\text { section }\end{array}$} & \multirow[b]{2}{*}{ Element } & \multicolumn{4}{|c|}{ A. cordata } & \multicolumn{4}{|c|}{ A. platanoides } \\
\hline & & Control & EW only & CGW only & EW and CGW & Control & EW only & CGW only & EW and CGW \\
\hline \multirow[t]{6}{*}{ Branch } & $\mathrm{N}$ & $1.04 \pm 0.06$ & $0.96 \pm 0.06$ & $1.08 \pm 0.07$ & $0.98 \pm 0.04$ & $0.43 \pm 0.03$ & $0.44 \pm 0.02$ & $0.45 \pm 0.02$ & $0.46 \pm 0.02$ \\
\hline & C & $50.64 \pm 0.23$ & $50.68 \pm 0.24$ & $50.94 \pm 0.20$ & $50.38 \pm 0.22$ & $48.33 \pm 0.22$ & $48.15 \pm 0.32$ & $47.78 \pm 0.25$ & $48.24 \pm 0.25$ \\
\hline & $\mathrm{K}$ & $0.57 \pm 0.02$ & $0.56 \pm 0.04$ & $0.61 \pm 0.02$ & $0.60 \pm 0.01$ & $0.76 \pm 0.07$ & $0.81 \pm 0.08$ & $0.90 \pm 0.09$ & $0.84 \pm 0.05$ \\
\hline & $\mathrm{Ca}$ & $0.76 \pm 0.05$ & $0.67 \pm 0.04$ & $0.69 \pm 0.05$ & $0.64 \pm 0.06$ & $1.20 \pm 0.15$ & $1.15 \pm 0.07$ & $1.16 \pm 0.07$ & $1.08 \pm 0.08$ \\
\hline & $\mathrm{Mg}$ & $0.08 \pm 0.01$ & $0.08 \pm 0.00$ & $0.08 \pm 0.00$ & $0.08 \pm 0.01$ & $0.10 \pm 0.01$ & $0.10 \pm 0.01$ & $0.11 \pm 0.00$ & $0.11 \pm 0.01$ \\
\hline & $\mathrm{P}$ & $0.07 \pm 0.00$ & $0.08 \pm 0.01$ & $0.08 \pm 0.00$ & $0.07 \pm 0.00$ & $0.09 \pm 0.00$ & $0.08 \pm 0.01$ & $0.10 \pm 0.01$ & $0.10 \pm 0.01$ \\
\hline \multirow[t]{6}{*}{ Stem } & $\mathrm{N}$ & $0.46 \pm 0.03$ & $0.53 \pm 0.01$ & $0.47 \pm 0.02$ & $0.51 \pm 0.03$ & $0.28 \pm 0.01$ & $0.28 \pm 0.01$ & $0.29 \pm 0.01$ & $0.28 \pm 0.02$ \\
\hline & c & $49.36 \pm 0.01 a$ & $50.23 \pm 0.12 b^{* * *}$ & $49.87 \pm 0.07 a b$ & $50.24 \pm 0.22 b^{* * *}$ & $48.63 \pm 0.16$ & $48.92 \pm 0.28$ & $48.76 \pm 0.17$ & $48.69 \pm 0.16$ \\
\hline & $\mathrm{K}$ & $0.28 \pm 0.01$ & $0.30 \pm 0.01$ & $0.28 \pm 0.02$ & $0.32 \pm 0.02$ & $0.35 \pm 0.02$ & $0.36 \pm 0.03$ & $0.40 \pm 0.01$ & $0.40 \pm 0.03$ \\
\hline & $\mathrm{Ca}$ & $0.29 \pm 0.06$ & $0.41 \pm 0.04$ & $0.35 \pm 0.03$ & $0.39 \pm 0.04$ & $0.36 \pm 0.03$ & $0.36 \pm 0.01$ & $0.38 \pm 0.04$ & $0.34 \pm 0.04$ \\
\hline & $\mathrm{Mg}$ & $0.03 \pm 0.00$ & $0.04 \pm 0.00$ & $0.03 \pm 0.00$ & $0.04 \pm 0.00$ & $0.05 \pm 0.00$ & $0.05 \pm 0.00$ & $0.04 \pm 0.00$ & $0.04 \pm 0.00$ \\
\hline & $\mathrm{P}$ & $0.04 \pm 0.00$ & $0.05 \pm 0.01$ & $0.04 \pm 0.00$ & $0.04 \pm 0.00$ & $0.05 \pm 0.00$ & $0.05 \pm 0.00$ & $0.05 \pm 0.00$ & $0.05 \pm 0.00$ \\
\hline \multirow[t]{6}{*}{ Leaves } & $\mathrm{N}$ & $2.83 \pm 0.06$ & $2.88 \pm 0.15$ & $2.91 \pm 0.07$ & $2.81 \pm 0.06$ & $1.20 \pm 0.05$ & $1.21 \pm 0.07$ & $1.23 \pm 0.05$ & $1.31 \pm 0.06$ \\
\hline & c & $53.13 \pm 0.22$ & $52.89 \pm 0.20$ & $53.01 \pm 0.09$ & $52.9 \pm 0.13$ & $48.98 \pm 0.31$ & $48.66 \pm 0.23$ & $49.22 \pm 0.30$ & $49.11 \pm 0.21$ \\
\hline & K & $0.66 \pm 0.02$ & $0.74 \pm 0.06$ & $0.73 \pm 0.04$ & $0.70 \pm 0.01$ & $0.86 \pm 0.03$ & $0.96 \pm 0.09$ & $1.03 \pm 0.10$ & $0.99 \pm 0.07$ \\
\hline & $\mathrm{Ca}$ & $0.94 \pm 0.07$ & $0.94 \pm 0.07$ & $0.87 \pm 0.07$ & $0.99 \pm 0.10$ & $1.34 \pm 0.04$ & $1.32 \pm 0.08$ & $1.05 \pm 0.09$ & $1.16 \pm 0.10$ \\
\hline & $\mathrm{Mg}$ & $0.13 \pm 0.01$ & $0.14 \pm 0.00$ & $0.14 \pm 0.01$ & $0.13 \pm 0.01$ & $0.20 \pm 0.01$ & $0.20 \pm 0.02$ & $0.17 \pm 0.01$ & $0.18 \pm 0.02$ \\
\hline & $\mathrm{P}$ & $0.12 \pm 0.01$ & $0.13 \pm 0.01$ & $0.13 \pm 0.01$ & $0.12 \pm 0.01$ & $0.14 \pm 0.02$ & $0.12 \pm 0.01$ & $0.15 \pm 0.01$ & $0.14 \pm 0.01$ \\
\hline Fine root 0 - & $\mathrm{N}$ & $1.39 \pm 0.10$ & $1.22 \pm 0.04$ & $1.16 \pm 0.12$ & $1.39 \pm 0.14$ & $0.73 \pm 0.02$ & $0.65 \pm 0.07$ & $0.73 \pm 0.06$ & $0.84 \pm 0.18$ \\
\hline \multirow[t]{5}{*}{$0.2 \mathrm{~m}$} & C & $44.62 \pm 1.51$ & $44.80 \pm 0.89$ & $44.73 \pm 0.62$ & $45.93 \pm 0.62$ & $45.43 \pm 0.78$ & $44.34 \pm 1.96$ & $43.35 \pm 2.85$ & $37.43 \pm 3.71$ \\
\hline & $\mathrm{K}$ & $0.43 \pm 0.02$ & $0.44 \pm 0.02$ & $0.47 \pm 0.03$ & $0.45 \pm 0.01$ & $0.76 \pm 0.03$ & $0.79 \pm 0.03$ & $0.77 \pm 0.05$ & $0.82 \pm 0.06$ \\
\hline & $\mathrm{Ca}$ & $1.45 \pm 0.08 a b$ & $1.69 \pm 0.06 b^{*}$ & $1.41 \pm 0.08 a$ & $1.42 \pm 0.05 a b$ & $1.64 \pm 0.19$ & $1.53 \pm 0.08$ & $1.50 \pm 0.09$ & $1.88 \pm 0.35$ \\
\hline & $\mathrm{Mg}$ & $0.17 \pm 0.01$ & $0.19 \pm 0.01$ & $0.18 \pm 0.01$ & $0.16 \pm 0.01$ & $0.29 \pm 0.07$ & $0.21 \pm 0.03$ & $0.21 \pm 0.02$ & $0.25 \pm 0.01$ \\
\hline & $\mathrm{P}$ & $0.07 \pm 0.01$ & $0.09 \pm 0.01$ & $0.09 \pm 0.01$ & $0.08 \pm 0.01$ & $0.15 \pm 0.01$ & $0.14 \pm 0.02$ & $0.15 \pm 0.01$ & $0.15 \pm 0.02$ \\
\hline Fine root & $\mathrm{N}$ & $0.94 \pm 0.04$ & $1.01 \pm 0.04$ & $0.95 \pm 0.04$ & $1.03 \pm 0.03$ & $0.60 \pm 0.03$ & $0.52 \pm 0.04$ & $0.54 \pm 0.03$ & $0.53 \pm 0.04$ \\
\hline \multirow[t]{5}{*}{$0.2-0.4 \mathrm{~m}$} & C & $44.49 \pm 1.26$ & $44.47 \pm 1.25$ & $43.06 \pm 1.56$ & $46.11 \pm 0.47$ & $34.6 \pm 1.79$ & $34.83 \pm 2.73$ & $29.61 \pm 1.89$ & $30.48 \pm 1.87$ \\
\hline & K & $0.44 \pm 0.02$ & $0.47 \pm 0.02$ & $0.45 \pm 0.03$ & $0.51 \pm 0.02$ & $0.89 \pm 0.05$ & $0.87 \pm 0.07$ & $0.84 \pm 0.06$ & $0.81 \pm 0.04$ \\
\hline & $\mathrm{Ca}$ & $1.65 \pm 0.14$ & $1.73 \pm 0.15$ & $1.65 \pm 0.09$ & $1.54 \pm 0.10$ & $1.88 \pm 0.12$ & $1.81 \pm 0.14$ & $1.84 \pm 0.08$ & $1.97 \pm 0.16$ \\
\hline & $\mathrm{Mg}$ & $0.17 \pm 0.02$ & $0.18 \pm 0.01$ & $0.17 \pm 0.01$ & $0.15 \pm 0.01$ & $0.27 \pm 0.02$ & $0.23 \pm 0.01$ & $0.27 \pm 0.02$ & $0.29 \pm 0.02$ \\
\hline & $\mathrm{P}$ & $0.07 \pm 0.00$ & $0.07 \pm 0.01$ & $0.07 \pm 0.00$ & $0.08 \pm 0.00$ & $0.14 \pm 0.01$ & $0.14 \pm 0.01$ & $0.15 \pm 0.02$ & $0.15 \pm 0.02$ \\
\hline \multirow[t]{6}{*}{ Main root } & $\mathrm{N}$ & $0.7 \pm 0.05$ & $0.80 \pm 0.10$ & $0.71 \pm 0.05$ & $0.70 \pm 0.03$ & $0.35 \pm 0.02$ & $0.34 \pm 0.02$ & $0.33 \pm 0.02$ & $0.37 \pm 0.01$ \\
\hline & C & $48.42 \pm 0.16$ & $48.45 \pm 0.47$ & $48.05 \pm 0.52$ & $48.61 \pm 0.24$ & $47.53 \pm 0.13$ & $47.16 \pm 0.23$ & $47.34 \pm 0.07$ & $47.63 \pm 0.35$ \\
\hline & $\mathrm{K}$ & $0.39 \pm 0.03$ & $0.41 \pm 0.02$ & $0.42 \pm 0.02$ & $0.39 \pm 0.00$ & $0.49 \pm 0.02$ & $0.52 \pm 0.04$ & $0.47 \pm 0.02$ & $0.54 \pm 0.03$ \\
\hline & $\mathrm{Ca}$ & $0.71 \pm 0.11$ & $0.80 \pm 0.15$ & $0.69 \pm 0.08$ & $0.64 \pm 0.06$ & $0.39 \pm 0.04$ & $0.46 \pm 0.05$ & $0.39 \pm 0.03$ & $0.40 \pm 0.03$ \\
\hline & $\mathrm{Mg}$ & $0.08 \pm 0.01$ & $0.09 \pm 0.01$ & $0.08 \pm 0.01$ & $0.07 \pm 0.01$ & $0.07 \pm 0.01$ & $0.08 \pm 0.01$ & $0.07 \pm 0.00$ & $0.07 \pm 0.00$ \\
\hline & $\mathrm{P}$ & $0.05 \pm 0.00$ & $0.07 \pm 0.02$ & $0.06 \pm 0.01$ & $0.05 \pm 0.00$ & $0.08 \pm 0.01$ & $0.08 \pm 0.01$ & $0.07 \pm 0.00$ & $0.08 \quad 0.00$ \\
\hline
\end{tabular}




\begin{tabular}{|c|c|c|c|c|c|c|c|c|}
\hline \multirow[b]{2}{*}{ Tree section } & \multicolumn{4}{|c|}{ A. cordata } & \multicolumn{4}{|c|}{ A. platanoides } \\
\hline & Control & $\begin{array}{r}\text { Earthworm } \\
\text { only }\end{array}$ & CGW only & $\begin{array}{l}\text { Earthworm } \\
\text { and CGW }\end{array}$ & Control & $\begin{array}{r}\text { Earthworm } \\
\text { only }\end{array}$ & CGW only & $\begin{array}{l}\text { Earthwơfin } \\
\text { and CGW }\end{array}$ \\
\hline Branch & $97.36 \pm 9.03$ & $75.24 \pm 9.56$ & $75.78 \pm 6.89$ & $69.25 \pm 6.86$ & $2.59 \pm 0.85$ & $2.22 \pm 0.22$ & $1.61 \pm 0.29$ & $4.08 \pm 1.12$ \\
\hline Leaves & $\mathrm{N} / \mathrm{A}$ & $N / A$ & $\mathrm{~N} / \mathrm{A}$ & $N / A$ & $6.01 \pm 1.18$ & $6.43 \pm 0.83$ & $6.32 \pm 0.90$ & $9.07 \pm 2.18$ \\
\hline Stem & $112.23 \pm 9.76$ & $121.21 \pm 7.94$ & $138.9 \pm 9.95$ & $109.87 \pm 6.36$ & $7.84 \pm 1.12$ & $10.17 \pm 1.60$ & $10.12 \pm 1.18$ & $12.56 \pm 2.02$ \\
\hline Total above & $209.59 \pm 17.32$ & $196.45 \pm 15.39$ & $214.68 \pm 14.28$ & $179.12 \pm 11.39$ & $16.44 \pm 3.10$ & $18.82 \pm 2.34$ & $18.05 \pm 2.25$ & $25.72 \pm 4.91$ \\
\hline Fine root 0.2 & $8.26 \pm 1.13$ & $12.48 \pm 2.66$ & $13.03 \pm 1.65$ & $8.04 \pm 0.34$ & $4.08 \pm 1.23$ & $3.91 \pm 1.11$ & $4.08 \pm 0.58$ & $4.03 \pm 0.83$ \\
\hline Fine root 0.4 & $17.30 \pm 2.78$ & $17.60 \pm 3.13$ & $15.76 \pm 2.44$ & $14.55 \pm 2.26$ & $4.70 \pm 1.41$ & $5.07 \pm 1.01$ & $5.20 \pm 0.84$ & $5.40 \pm 0.71$ \\
\hline Main root & $68.37 \pm 9.61$ & $60.90 \pm 5.84$ & $74.56 \pm 6.92$ & $57.82 \pm 6.97$ & $9.03 \pm 1.61$ & $9.65 \pm 1.23$ & $10.06 \pm 1.43$ & $15.06 \pm 4.30$ \\
\hline Total below & $93.92 \pm 11.67$ & $90.98 \pm 9.11$ & $103.36 \pm 8.04$ & $80.41 \pm 7.74$ & $17.82 \pm 4.13$ & $18.63 \pm 2.53$ & $19.34 \pm 2.19$ & $24.49 \pm 4.99$ \\
\hline Total tree & $303.51 \pm 28.44$ & $287.43 \pm 24.50$ & $318.03 \pm 18.49$ & $259.53 \pm 13.66$ & $34.25 \pm 7.17$ & $37.45 \pm 4.84$ & $37.39 \pm 4.34$ & $50.21 \pm 9.78$ \\
\hline
\end{tabular}


Table V. ANOVA table for F-value of the effect of CGW addition on reclaimed soil chemical parameters prior to use in field-based PVC mesocosms.

\begin{tabular}{|c|c|c|c|c|c|c|c|c|c|c|c|}
\hline \multirow{3}{*}{$\begin{array}{l}\text { Source of } \\
\text { variation }\end{array}$} & \multirow{3}{*}{ df } & \multicolumn{10}{|c|}{ Chemical parameter } \\
\hline & & $\mathrm{pH}$ & $\begin{array}{l}\text { Total } \\
(\%)\end{array}$ & $\mathrm{N}$ & $\begin{array}{l}\text { C (Org) } \\
(\%)\end{array}$ & O.M. (\%) & $\mathrm{C}: \mathrm{N}$ ratio & $\begin{array}{l}\mathrm{Ca} \\
(\mathrm{mg} / \mathrm{kg})\end{array}$ & $\begin{array}{l}{\left[\mathrm{N}\left(\mathrm{NO}_{3}{ }^{-}\right)\right]} \\
(\mathrm{mg} / \mathrm{kg})\end{array}$ & $\begin{array}{l}\mathrm{S}\left(\mathrm{SO}_{4}{ }^{2-}\right) \\
(\mathrm{mg} / \mathrm{kg})\end{array}$ & $\begin{array}{l}\mathrm{P}\left(\mathrm{PO}_{4}{ }^{3-}\right) \\
(\mathrm{mg} / \mathrm{kg})\end{array}$ \\
\hline & & $F$ & $F$ & & $F$ & $F$ & $F$ & $F$ & $F$ & $F$ & $F$ \\
\hline Treatment & 1 & $6.05^{*}$ & $52.63 * *$ & & $34.45^{* * *}$ & $34.45^{* * *}$ & $47.16^{* * *}$ & 7.30* & $73.38^{* * *}$ & $59.07^{* * *}$ & $188.45^{* * *}$ \\
\hline
\end{tabular}

$*$ Significant at $\mathrm{p}<0.05 . * *$ Significant at $\mathrm{p}<0.01 . * * *$ Significant at $\mathrm{p}<0.001 . \mathrm{n}=2$.

Table VI. ANOVA table for F-value of the effect of Italian alder on reclaimed soil chemical parameters after 12 months in field-based PVC mesocosms.

\begin{tabular}{|c|c|c|c|c|c|c|c|}
\hline \multirow{3}{*}{ Source of variation } & \multirow{3}{*}{$d f$} & \multicolumn{6}{|c|}{ Chemical parameter } \\
\hline & & $\begin{array}{ll}\mathrm{C} & \text { (Org) } \\
(\%) & \end{array}$ & $\begin{array}{l}\text { O.M. } \\
(\%)\end{array}$ & $\mathrm{K}$ & $\mathrm{Mg}$ & Moisture & $\mathrm{P}\left(\mathrm{PO}_{4}{ }^{3-}\right)(\mathrm{mg} / \mathrm{kg})$ \\
\hline & & $F$ & $F$ & $F$ & $F$ & $F$ & $F$ \\
\hline Tree species & 1 & $5.65^{*}$ & $5.65^{*}$ & $54.87^{* * *}$ & $1.15^{* * *}$ & $49.28 * * *$ & $6.41 * * *$ \\
\hline
\end{tabular}

* Significant at $\mathrm{p}<0.05$. ** Significant at $\mathrm{p}<0.01$. *** Significant at $\mathrm{p}<0.001 . \mathrm{n}=2$. 
Table VII. ANOVA table for F-value of the effect of CGW and earthworm addition on reclaimed soil chemical parameters under Italian alder trees after 12 months in field-based PVC mesocosms.

\begin{tabular}{|c|c|c|c|c|c|c|c|c|}
\hline \multirow{3}{*}{ Source of variation } & \multirow{3}{*}{$d f$} & \multirow{3}{*}{ Soil } & \multicolumn{6}{|c|}{ Chemical parameter } \\
\hline & & & Total N (\%) & C (Org) (\%) & O.M. (\%) & $\begin{array}{l}\mathrm{C}: \mathrm{N} \\
\text { ratio }\end{array}$ & $\mathrm{K}$ & {$\left[\mathrm{N}\left(\mathrm{NO}_{3}{ }^{-}\right)\right](\mathrm{mg} / \mathrm{kg})$} \\
\hline & & & $F$ & $F$ & $F$ & $F$ & $F$ & $F$ \\
\hline \multirow{2}{*}{ Treatment } & \multirow{2}{*}{4} & $0-0.2 \mathrm{~m}$ & $8.07^{* * *}$ & $3.45^{*}$ & $3.45^{*}$ & $3.96 *$ & $6.35 * * *$ & $1.35^{* * *}$ \\
\hline & & $0.2-0.4 \mathrm{~m}$ & $41.69 * * *$ & $13.25 * * *$ & $13.25 * * *$ & - & - & - \\
\hline
\end{tabular}

* Significant at $\mathrm{p}<0.05$. ** Significant at $\mathrm{p}<0.01 . * * *$ Significant at $\mathrm{p}<0.001 . \mathrm{n}=5$

Table VIII. ANOVA table for F-value of the effect of CGW and earthworm addition on reclaimed soil chemical parameters under Norway maple trees after 12 months in field-based PVC mesocosms.

\begin{tabular}{|c|c|c|c|c|c|c|c|}
\hline \multirow{3}{*}{ Source of variation } & \multirow{3}{*}{ df } & \multirow{3}{*}{ Soil } & \multicolumn{5}{|c|}{ Chemical parameter } \\
\hline & & & $\begin{array}{c}\text { Total N } \\
(\%)\end{array}$ & $\begin{array}{c}\text { C (Org) } \\
(\%)\end{array}$ & $\begin{array}{c}\text { O.M. } \\
(\%)\end{array}$ & K & $\begin{array}{l}\mathrm{P}\left(\mathrm{PO}_{4}{ }^{3-}\right) \\
(\mathrm{mg} / \mathrm{kg})\end{array}$ \\
\hline & & & $F$ & $F$ & $F$ & $F$ & $F$ \\
\hline \multirow{2}{*}{ Treatment } & \multirow{2}{*}{4} & $0-0.2 \mathrm{~m}$ & $15.32 * * *$ & $24.6 * * *$ & $24.6 * * *$ & $3.19 *$ & $5.39 *$ \\
\hline & & $0.2-0.4 m$ & $23.12^{*}$ & - & $17^{*}$ & - & $4.33^{*}$ \\
\hline
\end{tabular}

* Significant at $\mathrm{p}<0.05$. ** Significant at $\mathrm{p}<0.01 . * * *$ Significant at $\mathrm{p}<0.001 . \mathrm{n}=5$. 